Joanna Sztobryn-Giercuszkiewicz

Politechnika Łódzka

http://dx.doi.org/10.18778/8088-074-0.05

\title{
Alter idem - student z niepełnosprawnością w systemie szkolnictwa wyższego
}

\section{STRESZCZENIE}

Autorka przedstawia sytuację studentów niepełnosprawnych w systemie polskiego szkolnictwa wyższego. W pracy po raz pierwszy przedstawiona jest historia rozwoju systemów wsparcia edukacyjnego osób niepełnosprawnych na polskich uczelniach, zaprezentowane są też dwie perspektywy badawcze: z punktu widzenia instytucji szkolnictwa wyższego oraz samych studentów z niepełnosprawnościami. Autorka prezentuje wyniki najnowszych badań, „dobre praktyki” i rekomendacje dla systemu edukacji akademickiej dla zwiększonej inkluzji osób niepełnosprawnych w szkolnictwie wyższym.

Słowa kluczowe: niepełnosprawność, student, instytucje szkolnictwa wyższego, edukacja włączająca, inkluzja społeczna.

\section{WPROWADZENIE - O „NIEWIDZIALNYCH STUDENTACH}

Sytuacja osób z niepełnosprawnościami na uczelniach w Polsce w ciągu ostatnich dwudziestu lat uległa zasadniczym i spektakularnym zmianom. Obserwujemy stały wzrost liczby studentów niepełnosprawnych, niepowstrzymany 
mimo ogólnego spadku osób studiujących w populacji. Polskie uczelnie ulegają przemianom zarówno w aspekcie infrastrukturalnym, jak i świadomościowym - dosłownie i symbolicznie stają się przestrzeniami otwartymi dla tzw. „innych” - w tym również osób $\mathrm{z}$ różnego rodzaju niepełnosprawnościami. Zmienia się również prawo, które wymusza na systemie szkolnictwa wyższego konieczność zapewnienia osobom niepełnosprawnym równego dostępu do edukacji - od ratyfikowanej przez Polskę w 2012 r. Konwencji ONZ o prawach osób niepełnosprawnych, poprzez nowelizację ustawy Prawo o szkolnictwie wyższym, aż po szereg regulacji prawnych na poziomie samych uczelni. Jednak - pomimo tych wszystkich zmian - polscy studenci z niepełnosprawnościami pozostają wciąż w dużej mierze „niewidzialni” (Połtyn-Zaradna, Waszkiewicz, Zatońska 2009). W naszym społeczeństwie wciąż funkcjonuje dyskryminacyjny, negatywnie etykietujący sposób postrzegania osób niepełnosprawnych jako istot gorszych, słabszych, o widocznych deformacjach lub atrybutach (np. poruszających się na wózku, z białą laską) i w końcu - o niskim potencjale intelektualnym, co w sposób oczywisty, w społecznym mniemaniu, wyklucza tę grupę z szeroko pojętego środowiska akademickiego. Proces ten B. Gąciarz opisuje jako „podwójną lukę normatywną”: „W konsekwencji mamy do czynienia z [...] brakiem usankcjonowania dla osiągania wysokiego statusu społecznego tych ludzi (jest to postrzegane jako coś nienormalnego) i brakiem zinstytucjonalizowanych ścieżek osiągania przez nie takiego statusu. Tej kategorii osób naturalnie przypisuje się niski status społeczny" (Gąciarz 2010: 16).

Jak pokazują najnowsze kompleksowe badania (Ostrowska 2015; Gąciarz 2014) negatywne, stereotypowe i stygmatyzacyjne postawy wobec osób niepełnosprawnych nadal są w polskim społeczeństwie żywe, proces integracji społecznej powierzchowny, a otwartość, akceptacja i empatia często tylko czysto deklaratywne. Czy z podobnymi zjawiskami mamy do czynienia również na polskich uczelniach? Na ile - a może 
- czy w ogóle zmienia się podejście do niepełnosprawności w szkołach wyższych jako instytucjach edukacyjnych i w środowisku akademickim? Czy sami młodzi niepełnosprawni czują się włączeni w główny nurt życia akademickiego, na ile w nim faktycznie uczestniczą, jakie mają potrzeby i na ile różnią się one od potrzeb pozostałych studentów? Jaki jest pożądany kierunek zmian, ku czemu powinniśmy zdążać, aby zapewnić młodym osobom niepełnosprawnym prawo do edukacji akademickiej na poziomie faktycznej jego realizacji, a nie wyłącznie pięknych i pustych sloganów?

A może - trochę przewrotnie - „niewidzialność” tej grupy studentów nie jest efektem marginalizacji ich potrzeb, przysłowiowego „zamiatania pod dywan” ich problemów, a właśnie konsekwencją pełnej integracji, wtopienia się osób z niepełnosprawnością w społeczność akademicką, przyjęciem za normę ich obecności na uczelniach? Może już osiągnęliśmy inkluzję doskonałą i „inni” przestali istnieć, stali się „tacy sami”?

Rozważania poniższe będą próbą odpowiedzi na pojawiające się tu pytania w oparciu o prowadzone przez autorkę badania nad problematyką niepełnosprawności w polskim szkolnictwie wyższym i blisko dziesięcioletnie doświadczenie w pracy ze studentami z niepełnosprawnością na jednej z największych uczelni technicznych w Polsce. Przyjęta perspektywa będzie dotyczyła głównie młodych osób niepełnosprawnych (18-26 lat), z różnorodnymi niepełnosprawnościami, studiujących w polskich szkołach wyższych oraz ich relacjach z uczelnią i środowiskiem akademickim - wykładowcami, administracją uczelni, kolegami ze studiów.

\section{POCZA¿TKI EDUKACJI AKADEMICKIEJ OSÓB NIEPEŁNOSPRAWNYCH W POLSCE}

Historia kształcenia studentów z niepełnosprawnościami na polskich uczelniach, przynajmniej w ujęciu instytucjonalnym, nie jest zbyt długa. $Z$ całą pewnością uniwer- 
sytety od początku swojego istnienia kształciły pojedyncze osoby cierpiące na różnego rodzaju schorzenia i było to możliwe o tyle, o ile studenci ci radzili sobie sami lub z pomocą rodziny i życzliwych akademików, jednakże bez „uwypuklania” samego faktu ich niepełnosprawności. Jeszcze w latach 40-tych ubiegłego wieku F. Znaniecki (1997) pisał, iż status studenta określają m.in. „normalny stan zdrowia oraz umiejętności fizyczne pozwalające na wykorzystanie przedmiotów materialnych w życiu codziennym" (Znaniecki 1997: 40). Taki sposób myślenia trwał przez wiele dziesięcioleci na polskich uniwersytetach, a i dziś nie jest nieaktualny. Szkolnictwo wyższe w Polsce przeszło natomiast (szczególnie w latach 90-tych XX w.) ogromne przemiany, a boom edukacyjny spowodował zdecydowany wzrost liczby studentów (od 381 tys. w roku 1990 do ponad 1,5 mln w roku $2013^{1}$ ). Zmiany w sposobie myślenia, większa akceptacja dla integracyjnego modelu życia społecznego, a także popularyzacja w mediach pozytywnego wizerunku osób niepełnosprawnych (często przedstawianych jako super-bohaterów dzielnie wygrywających walkę z przeciwnościami losu) spowodowały, iż same osoby niepełnosprawne zaczęły otwierać się i uczestniczyć w życiu społecznym (Ostrowska 2015). Wraz ze wzrostem społecznej empatii obserwowany jest wzrost aktywności życiowej osób niepełnosprawnych, ich aspiracji rodzinnych i zawodowych, a także - co najważniejsze dla naszych rozważań - wzrost poziomu wykształcenia. Wszystkie te czynniki miały bez wątpienia wpływ na fakt, iż niepełnosprawna młodzież zaczęła w sposób widoczny pojawiać się na uczelniach.

Prawdopodobnie pierwszą uczelnią w Polsce, która w sposób świadomy zaczęła kształcić osoby niepełnosprawne była Wyższa Szkoła Rolniczo-Pedagogiczna w Siedlcach (obecnie Uniwersytet Przyrodniczo-Humanistyczny). To

1 „Szkoły wyższe i ich finanse”, Raporty GUS za lata 2001-2013 za: Inglot-Brzęk (2012). 
w tej właśnie uczelni zostało zawarte w 1994 r. porozumienie pomiędzy Ministrem Edukacji Narodowej a Ministerstwem Pracy i Polityki Socjalnej w sprawie powołania Centrum Kształcenia i Rehabilitacji Osób Niepełnosprawnych. Inicjatorem programu Kształcenia i Rehabilitacji Studentów Niepełnosprawnych był ówczesny Rektor WSRP w Siedlcach, prof. dr hab. Lesław Szczerba ${ }^{2}$. Program ten miał na celu umożliwienie osobom $\mathrm{z}$ niepełnosprawnością funkcjonowania $\mathrm{w}$ roli studenta na równych prawach tzn. możliwość pełnego uczestnictwa w zajęciach dydaktycznych, życiu naukowym, społecznym, kulturalnym i sportowym. Działania podejmowane w Centrum Kształcenia i Rehabilitacji Osób Niepełnosprawnych (pierwszej tego typu jednostce uczelnianej, wydzielonej merytorycznie i administracyjnie) to m.in. patronat nad procesem dydaktycznym, koordynacja pracy jednostek wspomagających kształcenie osób niepełnosprawnych (takich jak pracownia logopedii, pracownia tyfloinformatyki, poradnia psychologiczna, pracownie rehabilitacyjne, biblioteka) oraz stymulowanie samodzielności i efektywności studiów osób z niepełnosprawnościami. Działalność na rzecz studentów niepełnosprawnych siedleckiej uczelni była prapoczątkiem tego typu rozwiązań na wszystkich uczelniach w Polsce, a wypracowane tam metody i podejście - inspiracją dla późniejszych centrów tego typu w innych szkołach wyższych.

Przełom lat dwutysięcznych przyniósł istotne zmiany w systemie szkolnictwa wyższego, również w kontekście kształcenia studentów z niepełnosprawnościami. W największych ośrodkach akademickich w Polsce zaczęły powstawać specjalne działy, zajmujące się sprawami tej grupy studentów. W 2000 r. podobną do siedleckiej jednostkę powołano na Uniwersytecie Warszawskim. Jak można

2 Wszystkie dane odnośnie do CKiRON UPH w Siedlcach pochodzą ze strony internetowej uczelni www.ckiron.uph.edu.pl/index.php/pl/onas.html (dostęp 30.04.2015). 
przeczytać na stronach internetowych UW, Biuro ds. Osób Niepełnosprawnych (BON) było kontynuacją instytucji Pełnomocnika Rektora ds. Osób Niepełnosprawnych ${ }^{3}$. Uczelnia dostrzegła więc potrzebę wprowadzenia systemowych rozwiązań, głównie ze względu na „coraz większą ilość studentów niepełnosprawnych i przewlekle chorych zwracających się o pomoc, a co za tym idzie - ze względu na coraz większą liczbę usług świadczonych przez Uniwersytet" ${ }^{\text {. }}$ BON UW podjął się realizacji programu „Uniwersytet dla wszystkich”, a jego główne zadania koncentrowały się przede wszystkim wokół:

- bieżącej obsługi studentów i kandydatów niepełnosprawnych i przewlekle chorych,

- wsparcia dla pracowników dydaktycznych, w grupach których pojawili się studenci z niesprawnościami,

- działań na rzecz dostosowywania budynków i terenu uczelni dla osób z niesprawnością narządu ruchu,

- koordynacji transportu dla osób z niesprawnością narządu ruchu,

- organizacji stanowisk komputerowych oraz innych rozwiązań technologicznych dla studentów niepełnosprawnych,

- prowadzenia wypożyczalni sprzętu adaptacyjnego,

- prowadzenia biblioteki cyfrowej gromadzącej zbiory $\mathrm{w}$ formach dostępnych dla studentów niewidomych i słabowidzących.

Warto wspomnieć, że w Uniwersytecie Warszawskim, z inicjatywy Pełnomocnika Rektora ds. ON, powstała też w 1997 r. pierwsza Biblioteka Książek Cyfrowych, ówcześnie Biblioteka Książki Mówionej dla Osób Niewidomych. Zadaniem Biblioteki Książek Cyfrowych było udostępnianie i przygotowywanie w formie elektronicznej materiałów naukowych potrzebnych studentom w procesie kształcenia.

3 Źródło: www.bon.uw.edu.pl/bon.html (dostęp 30.04.2015).

4 Ibidem. 
Dziś UW kształci prawie 1000 studentów z różnego rodzaju niepełnosprawnościami, a tamtejszy BON jest jedną z największych i najlepiej rozwiniętych tego typu jednostek w kraju.

Z początkiem lat dwutysięcznych zaczęły się intensywnie rozwijać w tym aspekcie również krakowskie ośrodki akademickie. W 1999 r. na Uniwersytecie Jagiellońskim powołano Pełnomocnika Rektora ds. Osób Niepełnosprawnych, a w 2005 r., podobnie jak w UW, jego funkcję przekształcono w jednostkę uniwersytetu wspierającą kształcenie studentów niepełnosprawnych ${ }^{5}$. W tym czasie również inne uczelnie z Krakowa zaczęły organizować wsparcie edukacyjne dla studentów niepełnosprawnych - swoich Pełnomocników, a później Biura ds. Osób Niepełnosprawnych powołały Akademia Górniczo-Hutnicza, Akademia Pedagogiczna (dziś Uniwersytet Pedagogiczny im. KEN), Politechnika Krakowska, Akademia Ekonomiczna (dziś Uniwersytet Ekonomiczny). W związku ze stałym poszerzaniem wachlarza usług dla studentów $\mathrm{z}$ niepełnosprawnościami świadczonych przez te uczelnie, zostało zawarte porozumienie o współpracy, podpisane pierwotnie przez Rektorów AHG, PK i UEK w 2007 r., a następnie przez wszystkie największe krakowskie szkoły wyższe. Celem porozumienia była intensyfikacja współpracy między uczelniami w zakresie wsparcia studentów niepełnosprawnych, wymiana dobrych praktyk oraz lepsze wykorzystanie zasobów ${ }^{6}$.

Powoływanie Pełnomocników Rektorów ds. Osób Niepełnosprawnych, a następnie BON-ów, Centrów Wspierania Kształcenia itp. w polskich uczelniach pokazuje, iż studenci niepełnosprawni zaczęli pojawiać się w świadomości władz uczelni, a problematyka niepełnosprawności zyskiwać na znaczeniu. Jak wynika $\mathrm{z}$ informacji uzyskiwanych

5 Źródło: www.bon.uj.edu.pl/bon (dostęp 30.04.2015).

6 Źródło: www.up.krakow.pl/bon/porozumienie.html (dostęp 30.04.2015). 
w wywiadach od przedstawicieli uczelni, najczęściej jednak pierwszym impulsem ich tworzenia nie była chęć wdrożenia w uniwersytetach szczytnej ideologii edukacji włączającej, lecz po prostu - borykanie się z niedostosowaniem szkół wyższych do potrzeb osób z niepełnosprawnościami.

Istotnym problemem było też finansowanie organizowanego przez uczelnie wsparcia. W początkowym okresie tworzenia uczelnianych systemów wsparcia dla studentów z niepełnosprawnościami nie było żadnych specjalnych pieniędzy przeznaczonych na ten cel. Uniwersytety musiały radzić sobie same bądź korzystać z pomocy finansowej innych organizacji - tak było np. w przypadku Uniwersytetu Warszawskiego, gdzie wspólnie z PFRON uruchomiony został pilotażowy projekt na dostosowanie uczelni do potrzeb osób niepełnosprawnych. Projekt w latach 1999-2003 zrealizował budżet w wysokości ponad $15 \mathrm{mln}$ zł, przy czym blisko połowę sfinansował Państwowy Fundusz Rehabilitacji Osób Niepełnosprawnych, 33\% Uniwersytet Warszawski ze środków własnych, pozostałe inni darczyńcy ${ }^{7}$. Pieniądze te przeznaczone były głównie na likwidację barier architektonicznych i informacyjnych, transport oraz stypendia dla studentów niepełnosprawnych ${ }^{8}$. Inną strategię przyjęła Akademia Górniczo-Hutnicza w Krakowie, która w 2000 r. podjęła się realizacji wewnątrzuczelnianego grantu „AGH uczelnią przyjazną wobec osób niepełnosprawnych”, w ramach którego zaczęto likwidować bariery architektoniczne, powołano pewne struktury na wydziałach (pełnomocników dziekanów ds. osób niepełnosprawnych), zrealizowano też badania będące pierwszą diagnozą sytuacji studentów niepełnosprawnych na tejże uczelni (Gąciarz 2002). Inicjatywę przejęli tam też sami niepełnosprawni studenci, którzy w 2001 r. utworzyli pierwszą w Polsce organizację zrzeszają-

7 Źródło: www.bon.uw.edu.pl/pudw/spr_budzet.html (dostęp 10.09.2015).

8 Ibidem. 
cą studentów niepełnosprawnych (ZSN) i wywierali znaczący wpływ na działania uczelni w tym obszarze 9 .

W 2000 r. funkcjonowały też już w systemie szkolnictwa wyższego pewne instrumenty, które pozwalały określić liczbę studentów z niepełnosprawnością. Mechanizmy te opierały się o dane pochodzące $\mathrm{z}$ zestawień osób ubiegających się o wsparcie materialne na uczelniach. Pierwszym tego typu narzędziem było stypendium specjalne dla osób niepełnosprawnych. Stypendium to wypłacane było przez Ministerstwo Nauki i Szkolnictwa Wyższego studentom, którzy okazali się na uczelni orzeczeniem o stopniu niepełnosprawności (bądź dokumentem równoważnym). W związku z powyższym osoby te były rejestrowane przez uczelnię, która automatycznie zobligowana była przez MNiSW do corocznego raportu dotyczącego liczebności, stopnia i rodzaju niepełnosprawności swoich studentów. Uczelnie raportowały także od 2001 r. dane dotyczące niepełnosprawności wśród swoich studentów do GUS jako część dorocznego sprawozdania „Szkoły wyższe i ich finanse”.

Innym sposobem finansowego wsparcia studiujących osób niepełnosprawnych był funkcjonujący już na początku lat dwutysięcznych PFRON-owski program STUDENT (później STUDENT II, obecnie część programu Aktywny Samorząd). Przeprowadzone analizy już na tamtym, wczesnym etapie tworzenia systemów wsparcia kształcenia dorosłych osób niepełnosprawnych pozwoliły stwierdzić, że jest znacząca dysproporcja między odsetkiem osób niepełnosprawnych legitymujących się wyższym wykształceniem a populacją ogólną (dla porównania w 2007 r. było to $5,7 \%$ populacji osób niepełnosprawnych w wieku produkcyjnym w stosunku do $15,7 \%$ ogółem $^{10}$ ). Jednocześnie wskaźniki zatrudnienia pokazywały, że niepełnosprawni

9 Wywiad z dnia 02.07.2015 z Andrzejem Wójtowiczem, kierownikiem BON AGH.

10 Źródło: GUS-BAEL 2007, II kwartał. 
z wykształceniem wyższym są zdecydowanie chętniej zatrudniani (27\%) niż niepełnosprawni z wykształceniem średnim ogólnokształcącym $(14,1 \%)^{11}$. Ponadto, dość niska stopa bezrobocia wśród osób niepełnosprawnych z wykształceniem wyższym (ok. 5,4 \%) wskazywała, iż wsparcie osób niepełnosprawnych w dążeniu do podnoszenia wykształcenia i kwalifikacji oznacza sukces w ich przyszłej aktywizacji zawodowej. Był to jeden z powodów, dla których od 2002 r. podjęto finansowanie programu „STUDENT kształcenie ustawiczne osób niepełnosprawnych”. Głównym celem programu było wyrównywanie szans osób niepełnosprawnych w zdobywaniu wykształcenia i - poprzez stałe podnoszenie kwalifikacji - przygotowanie tej grupy do rywalizacji na otwartym rynku pracy. Adresatami programu były osoby $\mathrm{z}$ orzeczonym umiarkowanym lub znacznym stopniem niepełnosprawności, studiujące na uczelniach bądź uczące się w szkołach policealnych lub kolegiach. Kolejne edycje programów PFRON wspomogły znacząco dużą rzeszę studentów niepełnosprawnych (np. w 2012 r. z programu Student II skorzystało 16520 osób ${ }^{12}$ ), którzy mogli uzyskaną pomoc finansową przeznaczyć m.in. na opłacenie czesnego za naukę, kosztów zakwaterowania i dojazdów, zakup książek i innych materiałów edukacyjnych itp. Programy pomocy materialnej dla studentów z niepełnosprawnościami pozwoliły częściowo zlikwidować, a przynajmniej zminimalizować jedną $\mathrm{z}$ największych barier w dostępie do szkolnictwa wyższego - ograniczenia finansowe ${ }^{13}$.

11 Dane za 2009 r. za: Śleboda (2012).

12 Źródło: „Informacja Rządu Rzeczypospolitej Polskiej o działaniach podejmowanych w 2012 r. na rzecz realizacji postanowień uchwały Sejmu Rzeczypospolitej Polskiej z dnia 1 sierpnia 1997 r. Karta Praw Osób Niepełnosprawnych”, Warszawa 2013.

13 Jak wynika z badań przeprowadzonych wśród studentów niepełnosprawnych 20 łódzkich szkół wyższych (publicznych i niepublicznych), aż 60\% z nich uważa, że koszty studiowania osoby z niepełnosprawnością są wyższe od tych samych kosztów w przypadku osoby zdrowej. 
Znaczącą zmianę systemową przyniosła jednak dopiero nowelizacja ustawy Prawo o szkolnictwie wyższym w 2007 r., kiedy to uczelnie publiczne zaczęly otrzymywać „Dotację na zadania związane z kształceniem i rehabilitacją leczniczą studentów niepełnosprawnych"14. Ustawa zobowiązała ministra właściwego do spraw szkolnictwa wyższego do określenia, w drodze rozporządzenia, zasad podziału dotacji dla uczelni, w tym również wspomnianej, co znalazło wyraz w załączniku nr 12 do rozporządzenia ministra nauki i szkolnictwa wyższego z dnia 2 kwietnia 2007 r. w sprawie zasad podziału dotacji z budżetu państwa dla uczelni publicznych i niepublicznych (Dz.U. Nr 79, poz. 534). Zasady określone w tym załączniku uzależniają wysokość otrzymywanej przez poszczególne uczelnie publiczne dotacji od liczby studentów niepełnosprawnych studiujących na studiach stacjonarnych i niestacjonarnych, przeliczonej według wag dotyczących określonych grup niepełnosprawności.

Przekazywanie uczelniom środków na zadania związane z kształceniem i rehabilitacją leczniczą studentów niepełnosprawnych było niewątpliwie ogromnym krokiem naprzód, stwarzającym osobom z niepełnosprawnościami możliwość uczestniczenia w kształceniu akademickim w sposób pełny i na równych prawach. Jednocześnie jednak $\mathrm{z}$ dotacją pojawiło się wiele wątpliwości związanych $\mathrm{z}$ właściwym wydatkowaniem przekazywanych przez MNiSW środków. Ze względu na niedookreślenie, co ustawodawca rozumie przez „zadania związane z kształceniem i rehabilitacją leczniczą," uczelnie nie do końca się orientowały, na jakie działania de facto mogą przeznaczyć wspomnianą dotację. Spowodowało to w części szkół wyższych znaczne ograniczenie oferty wsparcia do niebudzącego wątpliwości minimum.

45\% ankietowanych wyraziło opinię, że jedną z największych przeszkód w studiowaniu jest ich niski status materialny (Sztobryn-Giercuszkiewicz 2011b).

14 Zgodnie z art. 94 ust. 1 pkt 11 ustawy z dnia 27 lipca 2005 r. - Prawo o szkolnictwie wyższym (Dz.U. Nr 164, poz. 1365, z późn. zm.) 
Z badań przeprowadzonych w 2010 r. wśród przedstawicieli 20 łódzkich uczelni publicznych i niepublicznych wynika, że tylko 3 uczelnie publiczne i 4 niepubliczne miały jakąkolwiek ofertę wsparcia dla swoich niepełnosprawnych studentów. Pozostałe uczelnie bądź nie miały swoim studentom nic do zaoferowania, bądź nie miały nawet orientacji co do faktu studiowania na ich uczelniach przez osoby z niepełnosprawnościami (Sztobryn-Giercuszkiewicz 2011a). Sytuacja ta obrazuje, iż część uczelni mimo otrzymywania dotacji na wsparcie studentów niepełnosprawnych nie miała za bardzo pomysłu co do jej zagospodarowania. Brak wytycznych ministerialnych, odpowiednich rozporządzeń, luki w ustawodawstwie dotyczącym osób niepełnosprawnych oraz stosunkowo mała styczność z tą problematyką w środowisku akademickim - były najprawdopodobniej powodami takiego stanu rzeczy.

Dotacja powyższa miała jeszcze jedną istotną wadę - nie można jej było wykorzystywać na dostosowanie uczelnianych budynków do potrzeb osób niepełnosprawnych ruchowo, podczas gdy bariery architektoniczne uważane są przez samych studentów niepełnosprawnych za jeden $\mathrm{z}$ najważniejszych elementów ograniczających osobom z niepełnosprawnościami dostępność szkół wyższych (Sztobryn-Giercuszkiewicz 2011b). Do chwili obecnej konstrukcja dotacji ministerialnej nie uległa zmianie pod tym względem, co oznacza, że uczelnie muszą pozyskiwać środki na dostosowywanie architektoniczne swoich budynków bądź ze źródeł zewnętrznych (nie do przecenienia są tu programy UE Kapitał Ludzki, POWER), bądź w ramach swoich środków na remonty i inwestycje. Taka konstrukcja dotacji powoduje znaczne zahamowanie likwidacji barier natury architektonicznej, szczególnie na uczelniach mniej zasobnych lub posiadających wiele starych budynków.

Wprowadzenie obligatoryjnej dotacji przeznaczonej na dostosowanie uczelni do potrzeb osób niepełnosprawnych było jednakże kamieniem milowym i spowodowało, że 
większość dużych, publicznych uniwersytetów i politechnik zaczęła realizować zadania związane z kształceniem i rehabilitacją leczniczą studentów niepełnosprawnych ${ }^{15}$.

W 2012 r. weszła w życie kolejna nowelizacja ustawy Prawo o szkolnictwie wyższym, zmieniająca przedmiot wspomnianej dotacji na „zadania związane ze stwarzaniem studentom i doktorantom, będącym osobami niepełnosprawnymi warunków do pełnego udziału $\mathrm{w}$ procesie kształcenia"16. Punkt ten został zmieniony na wniosek i po licznych konsultacjach ze środowiskami zaangażowanymi w prace nad zwiększaniem dostępności polskich uczelni dla osób niepełnosprawnych - Pełnomocnikami Rektorów ds. Osób Niepełnosprawnych, organizacjami pozarządowymi działającymi w sferze edukacji oraz samymi przedstawicielami studentów niepełnosprawnych. Otwartość na dia$\log$ i wsłuchanie się w potrzeby osób niepełnosprawnych zaowocowały ustaleniem zapisu $\mathrm{w}$ obecnym brzmieniu, które wydaje się być szersze zakresowo w stosunku do poprzedniego sformułowania przedmiotu dotacji. Zmiana ta poszerzyła obszar zadań możliwych do sfinansowania z dotacji, który przestał się ograniczać wyłącznie do kształcenia, a obejmować zaczął całokształt działań związanych ze stwarzaniem warunków do pełnego udziału w tym procesie ${ }^{17}$. Nadal jednak w bieżącym roku ze środków dotacji nie można finansować remontów i inwestycji związanych z np. bu-

15 Raport Fundacji Instytut Rozwoju Regionalnego Dobre praktyki. Wydatkowanie dotacji na zadania zwiazane $z$ kształceniem i rehabilitacja lecznicza studentów niepetnosprawnych, Kraków 2011.

16 Art. 94.1 pkt. 11 ustawy z dnia 27 lipca 2005 r. - Prawo o szkolnictwie wyższym, Dz.U. Nr 164, poz. 1365, z późn. zm.

17 O poszerzenie tego zakresu starano się przy konsultacjach zmian ze środowiskiem akademickim. Interpretację taką także przyjmują najczęściej uczelnie, np. pokrywając ze środków dotacji pomoc psychologiczną, która niewątpliwie jest niezbędna części grupy studentów z niepełnosprawnościami do pełnego udziału w procesie kształcenia. Jak dotąd nie wiadomo jednak, co to oznacza w praktyce, ustawodawca nie sprecyzował bowiem pojęcia „pełnego udziału w procesie kształcenia”. 
dową podjazdów czy instalacją wind na uczelniach, mimo iż jest to niewątpliwie jeden z podstawowych warunków związanych z pełnym udziałem części osób niepełnosprawnych $\mathrm{w}$ procesie kształcenia.

Inną ważną zmianą wynikającą z nowelizacji ustawy było rozszerzenie działań wspierających także na doktorantów niepełnosprawnych. Była to grupa wcześniej zapomniana przez ustawodawcę, a liczba doktorantów (studentów trzeciego stopnia) z orzeczeniem o niepełnosprawności stale rośnie (w roku 2011/2012 było ich 648, w roku akad. 2013/2014 - 829 $)^{18}$. Doktoranci, podobnie jak studenci pierwszego i drugiego stopnia, od 2012 r. mogą korzystać ze stypendium specjalnego dla osób niepełnosprawnych, którego wysokość jest uzależniona od stopnia niepełnosprawności.

Ożywiona dyskusja w środowiskach akademickich toczyła się także wokół „rehabilitacji leczniczej osób niepełnosprawnych" jako przedmiotu dotacji z MNiSW. Nie było tu zgody między przedstawicielami różnych uczelni w Polsce, których część optowała za pozostawieniem rehabilitacji w obrębie działań uczelni na rzecz studentów z niepełnosprawnościami. Wynikało to z faktu, iż część szkół, takich jak Akademie Wychowania Fizycznego, miała dobre zaplecze rehabilitacyjne (własne sale i sprzęt rehabilitacyjny, własnych specjalistów np. fizjoterapii) oraz z szerokiego rozumienia pojęcia "rehabilitacja lecznicza” ${ }^{19}$. Ostatecznie zadania związane $\mathrm{z}$ rehabilitacją leczniczą studentów niepełnosprawnych zostały wykreślone z katalogu działań możliwych do sfinansowania $\mathrm{z}$ dotacji jako procesy, które nie są stricte związane z edukacją. Uznano, że uczelnie nie są zobowiązane do rehabilitacji leczniczej, są natomiast inne służby, które mają realizować to zadanie na rzecz osób

18 Raport GUS „Szkoły wyższe i ich finanse 2011, 2013”.

19 Jest ono definiowane np. jako „ogół świadczeń, mających na celu przywrócenie pełnej lub możliwej do osiągnięcia sprawności fizycznej i psychicznej, zdolności do pracy oraz poprawę jakości życia” - źródło: www.mz.gov.pl/leczenie/rehabilitacjalecznicza (dostęp 14.09.2015). 
niepełnosprawnych (np. służba zdrowia) i otrzymują na to środki z budżetu państwa.

Najistotniejszą jednak zmianą, poza wyżej wspomnianymi implikacjami modyfikacji przedmiotu dotacji, wydaje się być wprowadzenie do ustawy Prawo o szkolnictwie wyższym zapisu o „stwarzaniu osobom niepełnosprawnym warunków do pełnego udziału w procesie kształcenia i badaniach naukowych" jako podstawowego zadania uczelni ${ }^{20}$. Zapis ten spowodował konieczność dostosowania statutów uczelni i wprowadzenie do nich analogicznego sformułowania. Uczelnie od tamtego momentu są zobowiązane ustawowo do stwarzania równych szans edukacyjnych wszystkim kandydatom bez względu na stan zdrowia, co dotychczas jak wynika z wielu doświadczeń praktycznych, a także ilości spraw z tym związanych, napływających do Rzecznika Praw Obywatelskich - nie było aż tak oczywiste, jak się wydaje ${ }^{21}$.

\section{POLSKIE UCZELNIE WOBEC ZJAWISKA NIEPEŁNOSPRAWNOŚCI WŚRÓD STUDENTÓW}

W chwili obecnej mijają trzy lata od wprowadzenia w życie zapisów znowelizowanej ustawy i choć trudno jeszcze o kompleksową ocenę skutków tych zmian, pokusić się można o próbę diagnozy sytuacji studentów z niepełnosprawnościami w instytucjach szkolnictwa wyższego. W latach 2013-2014 zespół Biura ds. Osób Niepełnosprawnych Politechniki Łódzkiej przeprowadził badanie ankietowe, skierowane do przedstawicieli wszystkich szkół wyższych w Polsce ${ }^{22}$. Badanie uzupełnio-

20 Art. 13.1 pkt 9 ustawy Prawo o szkolnictwie wyższym.

21 Por. np. raport Równe szanse $w$ dostępie do edukacji osób z niepetnosprawnościami. Analiza i zalecenia, Biuletyn Rzecznika Praw Obywatelskich 2012, nr 7, Zasada równego traktowania. Prawo i praktyka, nr 3, Warszawa 2012.

22 Chodzi o szkoły publiczne i niepubliczne, włączając wyższe szkoły 
no wywiadami pogłębionymi z Pełnomocnikami Rektorów ds. Osób Niepełnosprawnych. Celem badania było ustalenie, na ile (i czy w ogóle) zmiany legislacyjne są wdrażane i realizowane przez uczelnie w Polsce oraz uzyskanie wiedzy na temat dobrych praktyk stosowanych w polskich szkołach wyższych, służących zapewnieniu studentom $\mathrm{z}$ niepełnosprawnościami warunków do pełnego udziału w procesie kształcenia.

W pierwszej kolejności interesująca wydała się kwestia ustalenia liczebności osób z niepełnosprawnościami studiujących na polskich uczelniach. W związku ze wspomnianym wcześniej obowiązkiem sprawozdawczości do GUS oraz MNiSW można było przypuszczać, że uczelnie dysponują informacją o liczebności studentów i doktorantów z niepełnosprawnościami. Wyniki badania potwierdziły te przypuszczenia, a $88 \%$ spośród badanych uczelni była w stanie podać konkretne liczby. Poniższy wykres pokazuje wzrost liczby studentów z niepełnosprawnościami w latach 2007-2012:

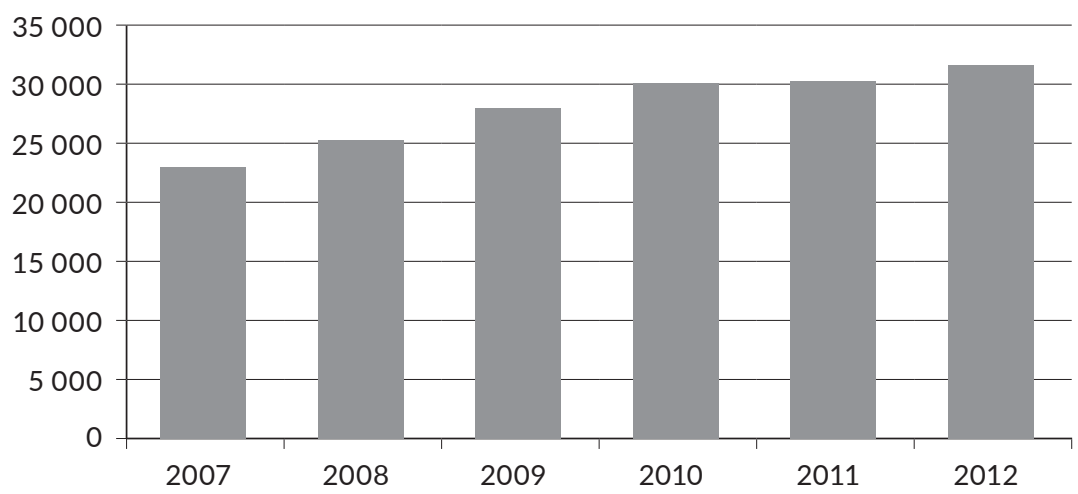

Wykres 1 . Wzrost liczby studentów z niepełnosprawnościami w latach 2007-2012

Źródło: opracowanie własne na podstawie GUS „Szkoły wyższe i ich finanse 2007-2012" 
Udział procentowy studentów niepełnosprawnych wobec ogółu osób studiujących wskazywany przez uczelnie jest zasadniczo spójny $\mathrm{z}$ danymi podawanymi $\mathrm{w}$ raporcie GUS „Szkoły wyższe i ich finanse w 2013 r.” oraz informacjami uzyskanymi $\mathrm{w}$ badaniu pilotażowym przeprowadzonym w łódzkich uczelniach w 2010 r. (Sztobryn-Giercuszkiewicz 2011a). Wszystkie te źródła wskazują na to, że studenci niepełnosprawni stanowią przeciętnie ok. 2\% wszystkich studentów danej uczelni, co stanowi znaczącą zmianę w stosunku do końca lat 90-tych ubiegłego wieku, kiedy to wskazywano na udział tej grupy wysokości ok. 0,5\% (Giermanowska $i$ in. 2015).

Nadal istnieje jednak dysproporcja $\mathrm{i}$,niedoreprezentowanie" tej grupy wśród ogółu studentów. Wystarczy zauważyć, że niemal co dziesiąty mieszkaniec Polski to osoba niepełnosprawna prawnie $\mathrm{w}$ wieku produkcyjnym, 34,1\% spośród nich posiada wykształcenie średnie, a $74,1 \%$ nie uczy się i nie pracuje ${ }^{23}$.

Analizując liczebność studentów pod względem stopnia niepełnosprawności, należy stwierdzić, że w większości uczelni przeważają studenci z lekkim i umiarkowanym stopniem niepełnosprawności (ponad połowa uczelni podała, że w ich przypadku jest to ponad 50 osób z każdym z tych stopni niepełnosprawności). W przypadku znacznego stopnia niepełnosprawności 94\% szkół stwierdziło, że jest to poniżej 50 osób na danej uczelni.

Ciekawe wydaje się też zestawienie liczebności studentów pod względem rodzaju niepełnosprawności. GUS zbiera informacje w podziale tylko na 4 kategorie: niesłyszący i słabosłyszący, niewidomi i słabowidzący, z dysfunkcją narządów ruchu (w podziale na chodzących i niechodzących) oraz inne rodzaje niepełnosprawności. Poniższy wykres obrazuje dane o rodzajach niepełnosprawności wśród studentów w roku 2013.

23 Dane MPiPS 2010, raport GUS za 2010 r., III kwartał. 


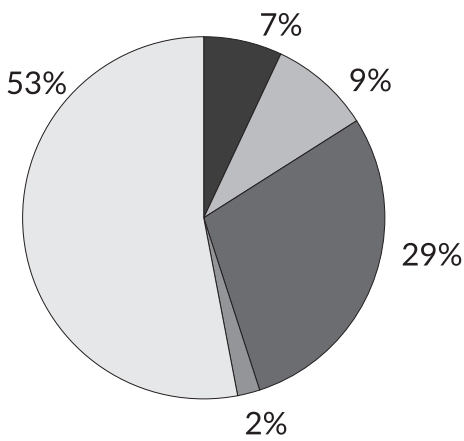

głusi i słabosłyszący

$\square$ niewidomi i słabowidzący

$\square$ z dysfunkcją ruchu chodzący

$\square$ z dysfunkcją ruchu niechodzący pozostali

Wykres 2. Dane o rodzajach niepełnosprawności wśród studentów w roku 2013

Źródło: opracowanie własne na podstawie GUS „Szkoły wyższe i ich finanse 2013"

Jak widać, najbardziej pojemną kategorią są „inne rodzaje niepełnosprawności”, na które składają się m.in. nowotwory, choroby wewnętrzne, alergie, zaburzenia psychiczne, przeszczepy, cukrzyca, epilepsja itp. Szkoda, że nie prowadzi się dokładniejszych statystyk, każda z tych jednostek chorobowych bowiem ma określone konsekwencje dla procesu kształcenia i wymaga odmiennych działań ze strony uczelni. Dookreślenie tych liczebności pozwoliłoby precyzyjniej planować proces dostosowywania uczelni do poszczególnych niepełnosprawności ${ }^{24}$.

24 Tu np. bardzo istotna z punktu widzenia dydaktycznego jest grupa studentów z orzeczoną niepełnosprawnością ze względu na zaburzenia psychiczne. $Z$ doświadczeń własnych i literatury przedmiotu (por. np. Izdebski 2010) wynika, że obecnie jest to grupa ok. 10\% wszystkich studentów niepełnosprawnych. Specyficzne potrzeby tej grupy, niewiedza środowiska akademickiego na temat postępowania z osobą z zaburzeniami psychicznymi i konsekwencje chorób psychicznych dla kształcenia powodują, że coraz częściej są ci studenci wymieniani jako odrębna kategoria niepełnosprawnych. 
Podsumowując powyższe dane, należy zwrócić uwagę na fakt, że ze względu na system sprawozdawczości oraz finansowania kształcenia niepełnosprawnych studentów ewidencjonowane są jedynie dane osób z orzeczoną niepełnosprawnością ${ }^{25}$. Należy przypuszczać, że osób niepełnosprawnych biologicznie (np. przewlekle chorych, czasowo niepełnosprawnych z powodu wypadków itp.), a nieposiadających dokumentu potwierdzającego niepełnosprawność jest na polskich uczelniach znacznie więcej, nie ma jednakże żadnego źródła danych o ich faktycznej liczebności. Innym jeszcze odcieniem sprawy danych o realnej liczbie studentów niepełnosprawnych jest fakt całkowitej dobrowolności podawania przez studenta informacji o niepełnosprawności. Liczebność studentów, o których informują uczelnie, jest więc z pewnością zaniżona w stosunku do rzeczywistej skali zjawiska. Brak informacji o niepełnosprawności oznacza dla studenta, że nie będzie mu przysługiwało stypendium specjalne dla osób niepełnosprawnych, zazwyczaj nie będzie on także objęty pomocą, jaką standardowo oferuje uczelnia studentom z niepełnosprawnością. Nieujawnianie informacji o swojej niepełnosprawności jest jednakże niezbywalnym, podstawowym prawem i autonomicznym wyborem każdego człowieka i uczelnie muszą to prawo szanować.

Wraz z rozpoczęciem przekazywania na uczelnie dotacji na kształcenie studentów niepełnosprawnych, a później wprowadzeniem zapisu o wyrównywaniu szans jako

25 Tzn. posiadających aktualne orzeczenie o stopniu niepełnosprawności bądź o niezdolności do pracy (lub dokument równoważny) w myśl ustawy z dnia 27 sierpnia 1997 r. o rehabilitacji zawodowej i społecznej oraz zatrudnianiu osób niepełnosprawnych (Dz.U. z $2011 \mathrm{Nr}$ 127, poz. 721, z późn. zm.). Zasadność stosowania zapisów powyższej ustawy w odniesieniu do szkolnictwa wyższego była wielokrotnie podważana przez środowisko akademickie, była też przedmiotem krytyki Rzecznika Praw Obywatelskich (por. Dostępność edukacji akademickiej dla osób z niepełnosprawnościami, Biuletyn Rzecznika Praw Obywatelskich 2015, nr 5, Zasada równego traktowania. Prawo i praktyka, nr 16, Warszawa). 
podstawowego zadania uczelni, szkoły wyższe zostały zobligowane i uzyskały narzędzie finansowe do udzielania specjalistycznego wsparcia swoim niepełnosprawnym studentom. Jak wykazało wyżej wspomniane badanie ankietowe, organizacja systemu wsparcia na uczelniach jest bardzo zróżnicowana i zależy w dużej mierze od wielkości uczelni, jej typu (publiczna/niepubliczna), a także indywidualnych uwarunkowań i wrażliwości na kwestię niepełnosprawności władz uczelni. Najlepiej zorganizowane, rozbudowane systemy wsparcia niepełnosprawnych studentów mają, czego można się było spodziewać, duże, akademickie, publiczne uczelnie. $\mathrm{W}$ ponad połowie $\mathrm{z}$ tych uczelni funkcjonują specjalnie wydzielone jednostki (lub nawet kilka jednostek), zajmujące się wsparciem studentów niepełnosprawnych na uczelni. Znacznie rzadziej tego typu jednostki funkcjonują w uczelniach niepublicznych i zawodowych szkołach wyższych. W tych uczelniach przeważa model jednoosobowy, głównie polegający na wyznaczeniu Pełnomocnika Rektora ds. Osób Niepełnosprawnych spośród kadry dydaktycznej uczelni. Respondenci wskazywali jednak także na takie osoby odpowiedzialne za wsparcie studentów z niepełnosprawnościami, jak np. doradca zawodowy z Biura Karier, Dyrektor Biblioteki czy nawet administrator budynku.

Organizacja systemu wsparcia studentów z niepełnosprawnościami na uczelni to także, a może w pierwszej kolejności, tworzenie ram formalno-prawnych tego systemu poprzez m.in. odpowiednie zapisy w statucie uczelni, strategie działań na rzecz osób niepełnosprawnych, zapisy w regulaminach wewnątrzuczelnianych (np. regulaminie studiów, rekrutacji), zarządzenia rektora itp. Tutaj 49\% spośród badanych uczelni wskazało, iż posiada zapisaną w dokumentach politykę działań na rzecz osób z niepełnosprawnościami; $12 \%$ ankietowanych przedstawicieli uczelni nie wie, czy takie zapisy istnieją. Pozostałe uczelnie (39\%) nie mają żadnych zapisów związanych z działaniami na rzecz tej grupy osób. Odrębną kwestią jest wdrażanie zapisanej polityki wobec osób 
niepełnosprawnych na uczelniach. Tu 83\% spośród szkół wyższych posiadających tego typu regulacje zadeklarowało, że zapisy te są wdrażane. Za wdrażanie tej polityki zazwyczaj odpowiedzialni są Pełnomocnicy Rektorów ds. Osób Niepełnosprawnych (44\% uczelni posiadających zapisy), dziekani (17\%) lub prorektorzy (14\%). Tylko w 12\% szkół odpowiada za to uczelniane biuro ds. osób $\mathrm{z}$ niepełnosprawnościami bądź inne osoby (rektor - 10\%, kanclerz - 6\%, samorząd studencki, koordynator ds. zarządzania jakością, „cała społeczność uczelni” - 9\%). Respondentom również trudno było odpowiedzieć na pytanie o monitorowanie wdrażania regulacji dotyczących studiowania osób niepełnosprawnych. $31 \%$ spośród tych uczelni, które posiadają zapisaną politykę i ją wdrażają deklaruje, że w żaden sposób tego nie monitoruje. Taki stan rzeczy pokazuje, że mimo iż istnieją odgórne założenia i ramy prawne obligujące uczelnie do tworzenia własnych regulacji prawnych w omawianym zakresie, na poziomie samych uczelni cały czas jeszcze systemy te są na wczesnym etapie tworzenia. Jednakże, biorąc pod uwagę, że świadomość uczelni w obszarze niepełnosprawności wśród studentów stale wzrasta, można mieć nadzieję, że za kilka lat i te kwestie będą na stałe włączone w standardy np. zarządzania jakością na uczelniach.

Ciekawym zagadnieniem jest także realna dostępność polskich szkół wyższych dla osób z niepełnosprawnościami. Pojęcie „dostępności” jest tu rozumiane szeroko, nie tylko popularnie jako brak barier architektonicznych, ale także jako uczestnictwo w życiu publicznym, korzystanie z dóbr kultury czy dostęp do informacji. Dyskryminacja osób z niepełnosprawnościami, według opracowania Biura Rzecznika Praw Obywatelskich, zauważana jest w szczególności w obszarze edukacji, zatrudnianiu osób niepełnosprawnych, zabezpieczaniu ich konkurencyjności na rynku pracy, a także korzystaniu z podstawowych praw i wolności obywatelskich, takich jak np. dostęp do służby publicznej, sądownictwa czy możliwość uczestniczenia w wyborach. 
W opracowaniu zwrócono uwagę także na wykluczenie cyfrowe, tj. brak dostępności serwisów i narzędzi internetowych oraz źródeł elektronicznych ${ }^{26}$.

Skupiając się na dostępności szkolnictwa wyższego w Polsce dla osób z niepełnosprawnościami, należy stwierdzić, że sytuacja pozostaje nadal daleka od ideału. Przyjmując deklarowanie przez uczelnię jakiejkolwiek formy wsparcia osób niepełnosprawnych jako zwiększanie dostępności, wyniki omawianych badań pokazują, że tylko ok. $30 \%$ uczelni jest w stanie udzielić szczegółowych informacji na ten temat. Wśród działań na rzecz studentów z niepełnosprawnościami, wymienianych przez przedstawicieli szkół wyższych, na pierwszym miejscu znalazła się pomoc materialna - 93\% respondentów wskazało tę formę wsparcia. Jest to zarówno stypendium specjalne dla osób niepełnosprawnych, jak i różnego rodzaju zapomogi, z których studenci z niepełnosprawnościami mogą korzystać na takich samych zasadach, jak pozostali. Nadmienić tu należy, że środki na wsparcie materialne dla studentów są uczelni przekazywane przez MNiSW i ta forma wsparcia nie ma charakteru fakultatywnego. Inne natomiast działania na rzecz studentów z niepełnosprawnością leżą całkowicie w gestii uczelni i zależą od świadomości, potencjału, zasobów i dobrej woli danej społeczności akademickiej. Badane uczelnie wymieniają tu wiele ciekawych aktywności na rzecz osób z niepełnosprawnościami, niewątpliwe zależnych od inwencji i rozpoznania potrzeb tej grupy studentów, tj.:

- możliwość zdawania egzaminów (wstępnych, semestralnych, końcowych) w alternatywnych formach; często występuje tu możliwość zamiany formy egzaminu z pisemnego na ustny lub odwrotnie, w zależności od niepełnosprawności studenta;

26 Zasada równego traktowania - prawo i praktyka. Dostępność infrastruktury publicznej dla osób z niepetnosprawnością. Analiza i zalecenia, Biuletyn Rzecznika Praw Obywatelskich 2011, nr 5. 
- zwiększanie mobilności poprzez zapewnienie specjalistycznego transportu (niektóre uczelnie mają własne działy transportowe, zajmujące się przewożeniem studentów na wózkach z domu na uczelnie i z powrotem) oraz asystentów transportowych osób niepełnosprawnych;

- zapewnienie możliwości wypożyczenia specjalistycznego sprzętu wspomagającego studiowanie; na wielu uczelniach funkcjonują tego typu wypożyczalnie, które w ofercie mają specjalistyczne urządzenia (np. laptopy ze specjalnym oprogramowaniem dla niewidomych, dyktafony, notatniki brajlowskie, przenośne systemy FM dla osób niedosłyszących, trackballe i specjalistyczne klawiatury i wiele innych);

- wsparcie „miękkie” w postaci aktywizacji zawodowej, konsultacji psychologicznych, doradztwa edukacyjnego oraz szkoleń służących rozwijaniu umiejętności psychospołecznych i związanych ze studiowaniem;

- zapewnienie specjalistycznych usług, np. tłumaczy języka migowego, tyflopedagogów, szkoleń $\mathrm{z}$ orientacji przestrzennej, logopedy, adaptacja materiałów dydaktycznych itp.;

- motywowanie do aktywności fizycznej poprzez dodatkowe lub dedykowane osobom z poszczególnymi rodzajami niepełnosprawności zajęcia wychowania fizycznego (np. koszykówka na wózkach, boccia, trójbój siłowy itp.) oraz rehabilitacja i fizjoterapia;

- możliwość indywidualnej organizacji studiów lub niektórych przedmiotów (np. indywidualne lektoraty z języków obcych dla osób słabosłyszących);

- dodatkowe wsparcie osobowe, np. asystenci osób niepełnosprawnych pomagający robić notatki lub podczas laboratoriów;

- organizacja zajęć integracyjnych, adaptacyjnych, wyjazdów, seminariów, obozów rehabilitacyjno-szkoleniowych itp.

Na wykresie 3 zaprezentowano rozkład odpowiedzi respondentów odnośnie do najczęściej oferowanych przez uczelnie form wsparcia niepełnosprawnych studentów. 


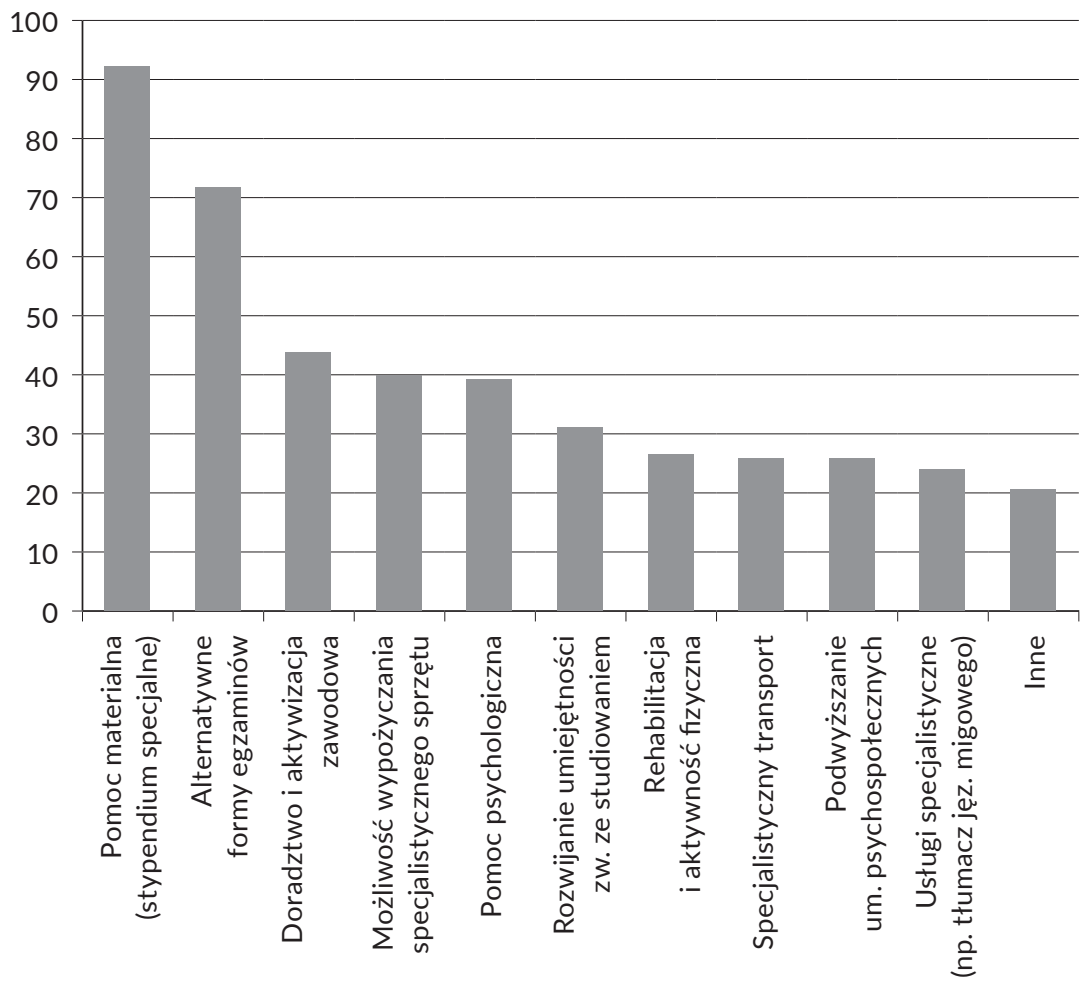

Wykres 3. Formy wsparcia studentów niepełnosprawnych przez uczelnie

Źródło: opracowanie własne na podstawie badań przedstawicieli polskich uczelni. Uwaga: odsetki nie sumują się do 100 ze względu na możliwość wyboru więcej niż jednej odpowiedzi.

Dodatkowo w wypowiedziach przedstawicieli uczelni pojawiały się także inne działania wspierające studentów z niepełnosprawnościami, jak np.:

- doposażanie uczelni w sprzęty umożliwiające studiowanie osobom $z$ różnego rodzaju niepełnosprawnościami (np. montaż w salach wykładowych pętli indukcyjnych, wspomagających słyszenie; likwidacja barier architektonicznych, zakup sprzętu umożliwiającego osobom nie- 
widomym i słabo widzącym korzystanie z materiałów dydaktycznych i bibliotek, tworzenie pracowni multimedialnych do lektoratów z jęz. obcych oraz bibliotek książki mówionej, dostosowane stanowiska komputerowe);

- specjalistyczne doradztwo i wsparcie relacji student z niepełnosprawnością - nauczyciel akademicki, „bieżące wspieranie wykładowców w rozwiązywaniu dylematów i trudności dot. kształcenia osób niepełnosprawnych. Informowanie o strategiach pracy ze studentami niepełnosprawnymi" (NP 64) ${ }^{27}$;

- digitalizacja materiałów dydaktycznych, „adaptacje materiałów dydaktycznych i egzaminów - brajl, powiększony druk, elektroniczne, grafika dotykowa (dotykowe diagramy, mapy, rysunki), dotykowa audiografika (udźwiękowiona grafika dotykowa)" (P77);

- „Portfolio jako alternatywna forma pracy magisterskiej studentów z głębokim uszkodzeniem słuchu (opcjonalnie do formy tradycyjnej w przypadku dużych trudności gramatycznych)" (NP52).

Dostępność architektoniczna, mimo iż gwarantowana m.in. w Prawie budowlanym ${ }^{28}$, jest bolączką polskich uczelni, na co zwrócono uwagę również w badaniach dostępności uczelni na terenie województw dolnośląskiego, lubuskiego i opolskiego ${ }^{29}$. W prezentowanych badaniach uczelni z lat

27 Skrót NP oznaczna uczelnię niepubliczną, P - publiczną, cyfra obok skrótu jest numerem respondenta.

28 Ustawa z dnia 7 lipca 1994 r. Prawo budowlane (Dz.U. z 2010 r. $\mathrm{Nr} 243$, poz. $1623 \mathrm{ze} \mathrm{zm}$.). Ustawodawca nie precyzuje, jakich udogodnień i zakresów niepełnosprawności dotyczy wymóg zapewnienia dostępności. Dodatkowo konieczność dostosowania dotyczy jedynie obiektów nowych i modernizowanych po 1 stycznia 1995 r., co oznacza, iż nie ma prawnych możliwości egzekwowania likwidacji barier w budynkach wybudowanych przed tą datą.

29 Dostępność szkolnictwa wyższego dla osób niepelnosprawnych $w$ województwach: dolnoślaskim, lubuskim i opolskim, Zespół Terenowy we Wrocławiu Biura Rzecznika Praw Obywatelskich, Wrocław 2007, [w:] Zasada równego traktowania - prawo i praktyka. Dostępność infrastruktu- 
2013-2014 niemal w połowie szkół większość budynków jest pozbawiona barier architektonicznych. Sporo uczelni, bo niemal co czwarta, zadeklarowało, iż wszystkie budynki są dostępne dla osób z niepełnosprawnością ruchową. Jednocześnie aż 30\% spośród badanych szkół jest całkowicie niedostosowanych bądź dostępne są tylko niektóre budynki. O likwidację barier architektonicznych w budynkach zdecydowanie częściej dbają uczelnie publiczne $(\mathrm{VCr}=0,33$; $\mathrm{p}=0,001)$ i akademickie $(\mathrm{VCr}=0,36 ; \mathrm{p}=0,0001)$.

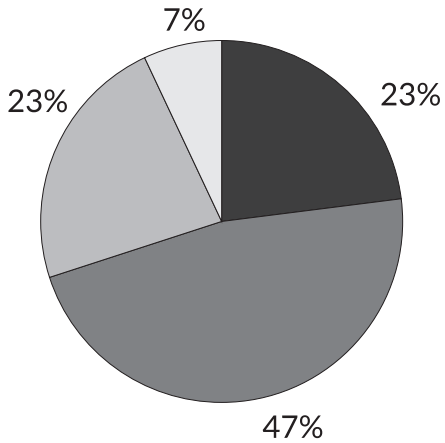

Wszystkie

Większość

$\square$ Niektóre

Żaden

Wykres 4. Dostępność architektoniczna budynków uczelni

Źródło: opracowanie własne na podstawie badań przedstawicieli polskich uczelni

Przeciwdziałanie wykluczeniu cyfrowemu to jeden z priorytetów Unii Europejskiej, której ponad $80 \mathrm{mln}$ niepełnosprawnych obywateli jest w mniejszym lub większym stopniu pozbawionych dostępu do usług elektronicznych ${ }^{30}$. Strony i serwisy internetowe, szczególnie instytucji publicznych, powinny być dostępne dla osób $\mathrm{z}$ różnego rodzaju

ry publicznej dla osób z niepetnosprawnością. Analiza i zalecenia, Biuletyn Rzecznika Praw Obywatelskich 2011, nr 5.

30 Badanie dostępności stron WWW. Raport otwarcia 2013, Fundacja Widzialni.org, http://www.widzialni.org/container/Raport_Otwarcia_2013.pdf 
niepełnosprawnościami. Dla osób o ograniczonej sprawności ruchowej i osób z dysfunkcją wzroku i słuchu Internet jest często głównym sposobem komunikacji ze światem zewnętrznym. Obowiązek dostosowania serwisów teleinformatycznych do potrzeb osób niepełnosprawnych nakłada m.in. Rozporządzenie Rady Ministrów z dnia 12 kwietnia 2012 r. w sprawie Krajowych Ram Interoperacyjności, minimalnych wymagań dla rejestrów publicznych i wymiany informacji w postaci elektronicznej oraz minimalnych wymagań dla systemów teleinformatycznych (Dz.U. z 2012, poz. 526). Zgodnie z par. 19 cytowanego Rozporządzenia, podmiot realizujący zadania publiczne musi zapewnić spełnienie przez system teleinformatyczny wymagań Web Content Accessibility Guidelines (WCAG 2.0). Przywołane wcześniej badanie dostępności stron WWW, przeprowadzone w 2013 r. na 114 serwisach instytucji publicznych, pokazało, że ponad $90 \%$ spośród tych serwisów nie spełnia podstawowych kryteriów WCAG $2.0^{31}$. Uczelnie, realizując prawo osób niepełnosprawnych do równego dostępu do edukacji i informacji, także powinny zadbać o spełnianie standardów WCAG 2.0 przez swoje serwisy internetowe. Jednak respondenci zapytani o dostępność stron internetowych swoich uczelni aż w $68 \%$ przyznali, że serwisy te nie są dostosowane do potrzeb osób niepełnosprawnych. 22\% uczelni zadeklarowało, że ich serwisy WWW spełniają standardy określone w Rozporządzeniu, a 10\% szkół wyższych jest $\mathrm{w}$ trakcie przygotowywania dostępnych serwisów.

$\mathrm{W}$ prezentowanym badaniu uczelnie wypowiedziały się też, co ich zdaniem należałoby zrobić, aby zapewnić osobom niepełnosprawnym lepsze wsparcie i dostęp do szkolnictwa wyższego w przyszłości. Na pierwszym miejscu stawiane jest zwiększenie świadomości pracowników w zakresie studiowania osób niepełnosprawnych. Niemal równie ważne wydaje się przedstawicielom uczelni

31 Ibidem. 
zwiększenie świadomości studentów pełnosprawnych co do zjawiska niepełnosprawności na uczelniach oraz zwiększenie finansowania na programy i projekty dotyczące studiowania osób niepełnosprawnych. Połowa uczelni opowiedziała się za wypracowaniem nowych, lepszych rozwiązań prawnych na poziomie krajowym oraz za zwiększeniem współpracy międzyuczelnianej. Podobnie ważne wydaje się być opracowanie przez uczelnie nowych strategii w tym obszarze.

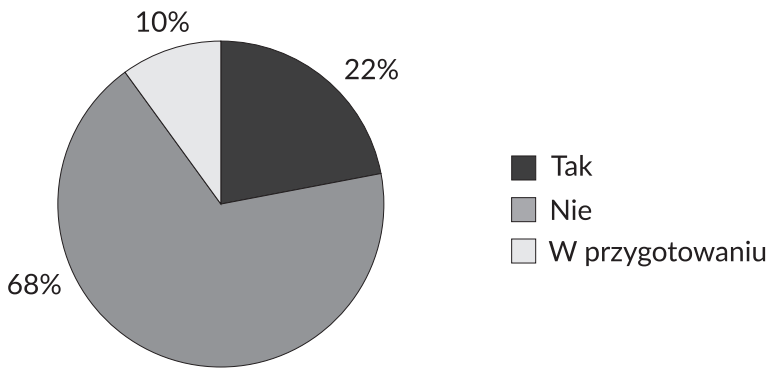

Wykres 5. Serwisy internetowe uczelni dostosowane do potrzeb osób niepełnosprawnych

Źródło: opracowanie własne na podst. badań przedstawicieli polskich uczelni

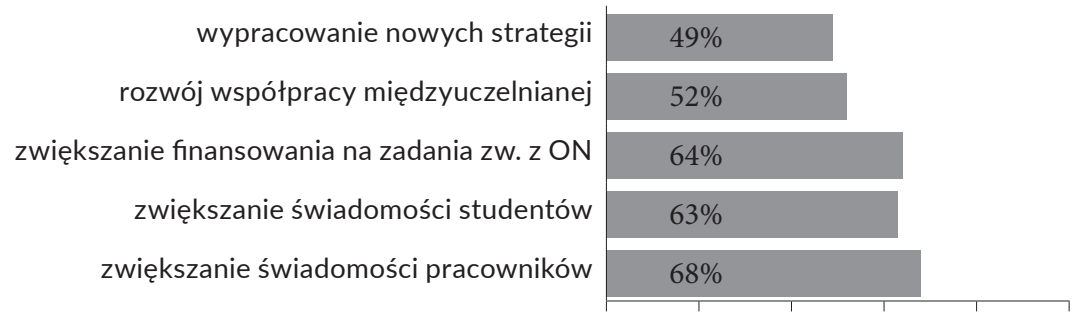

Wykres 6. Potencjalne działania, które należy podejmować, aby zapewnić osobom niepełnosprawnym wsparcie na uczelniach

Źródło: opracowanie własne na podstawie badań przedstawicieli polskich uczelni. Uwaga: odsetki nie sumują się do 100 ze względu na możliwość wyboru więcej niż jednej odpowiedzi 
Na zakończenie warto przytoczyć jeszcze głos Pełnomocnika Rektora ds. Osób Niepełnosprawnych jednej z uczelni niepublicznych na temat bolączek natury legislacyjnej polskiego systemu szkolnictwa wyższego:

A: Czy istnieja w Polsce jakieś regulacje prawne dotyczace kształcenia osób niepełnosprawnych na poziomie szkolnictwa wyższego?

R: Wg mnie i tak i nie - ze wskazaniem na "nie”. Tak bo uważam za obowiązujace pewne przepisy pojawiające się w różnych aktach prawnych, które wymagają dziatań antydyskryminacyjnych; można mówić o pewnym „duchu prawa”, które powinniśmy uwzględniać w działaniach na rzecz zwiększania dostępności uczelni dla osób z niepetnosprawnością. Nie - bo brak jednego głównego aktu prawnego czy nawet programu ministerialnego/rzadowego dotyczacego kształcenia ON na wyższych uczelniach, jak i dotyczacego osób niepełnosprawnych $w$ ogóle [...] Zapisy prawne sa rozproszone, sprzeczne, często wymagające „czytania między wierszami”, czyli w praktyce zależa od interpretacji instytucji. Poza tym ograniczony zakres rozporzadzeń o charakterze wykonawczym, jak również brak sankcji $z$ tytułu naruszenia prawa w tym zakresie, czyni nawet te istniejace zapisy martwymi i całkowicie zależnymi od dobrej woli urzędników czy jednostkowej polityki danej instytucji (NP4) ${ }^{32}$.

32 Warto dodać, że w przytaczanym badaniu z roku 2009 ponad połowa osób odpowiedzialnych za wsparcie studentów niepełnosprawnych w łódzkich uczelniach nie potrafiła wskazać konkretnych regulacji prawnych dotyczących sytuacji studentów niepełnosprawnych na uczelniach w Polsce, a $1 / 3 \mathrm{z}$ nich nie miała żadnej wiedzy na temat istnienia takich regulacji (Sztobryn-Giercuszkiewicz 2011a). 


\section{SEMPER IDEM ET ALTER - STUDIOWANIE OCZAMI POLSKICH STUDENTÓW Z NIEPEŁNOSPRAWNOŚCIAMI}

Ważnym wkładem, choć ciągle jeszcze za mało docenianym, w rozwój systemów wsparcia osób niepełnosprawnych na poziomie szkolnictwa wyższego jest oddanie głosu samym niepełnosprawnym studentom i wsłuchanie się w ich narracje dotyczące ścieżek edukacyjnych prowadzących na uczelnie, osób znaczących wspierających w tym procesie, barier utrudniających im „normalne” funkcjonowanie na uczelni, opinii dotyczących nastawień do nich nauczycieli i kolegów, a także postaw samych niepełnosprawnych studentów wobec różnorodnych aspektów funkcjonowania na uczelniach. Nie do przecenienia są tu opowieści o edukacyjnych sukcesach i porażkach, a także o ich aspiracjach i planach na przyszłość.

Próbą pogłębienia obrazu polskiego szkolnictwa wyższego w kontekście studiowania osób z niepełnosprawnościami było ogólnopolskie badanie, przeprowadzone przez zespół BON PŁ w latach 2014-2015 wśród 587 studentów niepełnosprawnych z 79 szkół wyższych różnego typu ${ }^{33}$. Ze względu na szeroki zakres badania, szczegółowe wyniki zostaną przedstawione w odrębnym raporcie, w niniejszym opracowaniu warto skupić się na pewnych leitmotivach przewijających się w wypowiedziach respondentów.

Droga do edukacji na poziomie wyższym nie jest dla młodzieży niepełnosprawnej prosta i należy mieć świadomość, że ci, którzy docierają do tego etapu (głównie

$33 \mathrm{~W}$ badaniu wzięli udział studenci uczelni publicznych i niepublicznych, w tym: uniwersytetów, politechnik, akademii, szkół zawodowych, medycznych, plastycznych i wychowania fizycznego. Studenci wypełniali ankietę internetową (CAWI), do której link był za ich zgodą rozsyłany na podane adresy mailowe przez uczelniane BONy lub pełnomocników rektorów ds. osób niepełnosprawnych. Elektroniczny formularz ankiety był przygotowany $\mathrm{w}$ formie dostępnej także dla osób $\mathrm{z}$ dysfunkcją wzroku. 
w przypadku głębszego stopnia niesprawności) to osoby nieprzeciętne, o ogromnej determinacji i dużym wsparciu otoczenia, najczęściej rodziny. Wielu (ponad 58\%) spośród badanych studentów było wspieranych w swoich decyzjach o kontynuacji nauki na uczelni i spotkało się z pozytywnymi reakcjami otoczenia. Czasem rodzice wspierają swoje niepełnosprawne dzieci, mimo obaw związanych z wyzwaniami, jakie stawia nauka na uczelni, często poza miejscem zamieszkania: Rodzice wspierali mnie, ale jednocześnie byli bardzo zaniepokojeni tym, że będę mieszkać sama $w$ innym mieście i jeśli coś się ze mna będzie działo, nie będzie miał kto mi pomóc $(\mathrm{R} 276)^{34}$. Dla większości ankietowanych kwestia podjęcia studiów była czymś zupełnie oczywistym i naturalnym: Nikt się nie dziwit - to było oczywiste (R34); Przecież to normalne, że osoba po skończeniu liceum wybiera się na studia (R312). Jednocześnie 11\% studentów spotkało się z negatywną reakcją otoczenia (zdziwienie lub próby zniechęcania): Większość mówiła, że pewnie nie dam rady, bo jestem osoba dializowana (R17); Bali się, że to pogorszy mój stan $z$ drowia (R223). Tylko 23\% ankietowanych studentów miało przed podjęciem studiów styczność z innymi studiującymi osobami niepełnosprawnymi, reszta się tą kwestią nie interesowała lub w ogóle nie słyszała o osobach niepełnosprawnych, które studiują lub ukończyły studia.

W wielu przypadkach studenci doświadczyli różnych trudności na wcześniejszych etapach edukacji (37\%), wynikających ze stanu zdrowia. Zdarzają się tego typu wypowiedzi: W Poznaniu jedynie (numer szkoły) LO było chętne do przyjęcia osoby na wózku. W innych "renomowanych” szkołach usłyszałam - nie widzimy ciebie tutaj, nawet jeśli się dostaniesz (co nie było problemem) nie zapewniamy lekcji na parterze; niech mama ci pomaga w pokonywaniu schodów (R14). Sytuacje takie z pewnością nie zdarzają się często, jednak sam fakt, że się nadal pojawiają, jest zatrważający.

34 Skrót oznacza osobę respondenta biorącego udział w badaniu. 
W przypadku ponad 25\% studentów stan zdrowia ograniczył w jakimś stopniu możliwości wyboru uczelni, głównie ze względu na niedostosowanie architektoniczne, ale także ze względu na odległość od domu rodzinnego lub konieczność pełnej sprawności fizycznej (uczelnie „mundurowe”, częściowo medyczne). Czasem z wachlarza możliwości odpadają też studia na uczelni technicznej (Mam epilepsje $i$ nie moge studiować na kierunkach technicznych, $z$ maszynami, odczynnikami (R433)) lub humanistycznej (Depresja i niepełnosprawność kończyn górnych uniemożliwiła mi wybór uczelni pedagogicznej ze względu na prace z dziećmi, które mogłyby się np. ze mnie naśmiewać. W ogóle taka praca byłaby niewskazana (R112)). Dla ponad połowy respondentów (52\%) jednak niepełnosprawność nie miała żadnego znaczenia przy wyborze kierunku studiów - Głównie liczyło się to, czym się interesuję i co chcę robić $w$ przyszłości, dopiero na samym końcu to, czy dam radę to robić (R84). Taka postawa bywa niestety często źródłem późniejszych rozczarowań: Niestety dowiedziałam się na 4 roku studiów, że moja niepełnosprawność nie pozwoli mi wykonywać wyuczonego zawodu (R354); Nie zdawałam sobie sprawy z tego, jak moja niepełnosprawność będzie się rozwijać w przyszłości, jak wpłynie na moje życie zawodowe. Dziś wybrałabym zupełnie inaczej (R127). Wypowiedzi takie wskazują na ogromną rolę doradztwa zawodowego i edukacyjnego dla niepełnosprawnej młodzieży, dzięki któremu przyszli studenci mogliby bardziej świadomie wybierać kierunki studiów i rodzaj wykonywanego w przyszłości zawodu, adekwatnie do swoich możliwości.

Miejsce studiowania było ważne dla $68 \%$ badanych studentów z niepełnosprawnością, przy czym dla ponad 22\% $\mathrm{z}$ nich miało decydujące znaczenie przy wyborze uczelni. Tutaj znowu pojawia się wątek chęci lub konieczności mieszkania z rodzicami, odległości do uczelni (mniejsza mobilność), opieki medycznej, kosztów. 60\% ankietowanych studentów wyprowadziło się z domu rodzinnego, by studiować, 
choć zdarzają się i takie wypowiedzi; Nie musiatem, ale i tak się wyprowadziłem. Najważniejsza dla mnie była samodzielność (R378). Jednocześnie niemal 40\% studentów z niepełnosprawnościami studiuje, nie mieszkając z rodzicami.

Ciekawa wydaje się kwestia, czy niepełnosprawni kandydaci na studia sprawdzają, które uczelnie są dostosowane najlepiej do ich potrzeb i jaką mają ofertę dla osób niepełnosprawnych. Poniższe wykresy przedstawiają rozkład wyników.

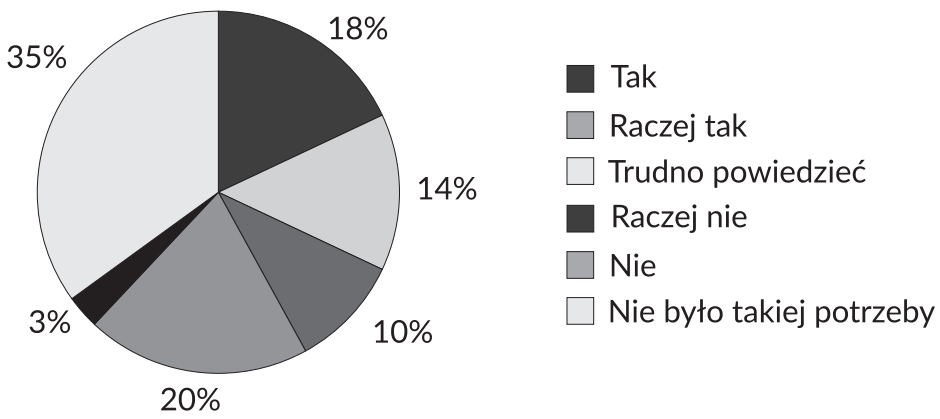

Wykres 7. Rozkład odpowiedzi na pytanie: Czy sprawdziłeś wcześniej dostosowanie uczelni do swoich potrzeb?

Źródło: opracowanie własne na podstawie badań studentów niepełnosprawnych

Wyniki takie potwierdzają analizy przeprowadzone wśród niepełnosprawnych studentów AGH, gdzie ponad $36 \% \mathrm{z}$ nich stwierdziło, że stan zdrowia prawie nigdy lub nigdy nie przeszkadza im w życiu codziennym i nauce (Myśliwiec 2010). W powyższym badaniu także zdecydowanie największa grupa to studenci z niepełnosprawnościami niewymagającymi specjalnych dostosowań ${ }^{35}$, choć na pytanie „Jeśli nie sprawdzałeś uczelni pod tym kątem, to dlaczego?"

35 Jedynie $13 \%$ badanych studentów uważa, że ich niepełnosprawność w dużym lub bardzo dużym stopniu utrudnia studiowanie. 
pojawiały się i takie wypowiedzi: Bez względu na dostępność uczelni zależało mi na podjęciu studiów ze względu na wysoki poziom kształcenia (R13) lub: Bo przyzwyczajona jestem, że budynki użyteczności publicznej nie sa dostosowane do moich potrzeb. Jakoś muszę sobie radzić (R218). O tym, czy uczelnia jest dostosowana do potrzeb osób z daną niepełnosprawnością, kandydaci czerpali wiedzę najczęściej z serwisów internetowych uczelni $(26,7 \%)$, z informacji od Pełnomocnika ds. ON/Biura ds. ON (10,6\%) lub zostali poinformowani w rekrutacji (10,4\%). Jednakże 42\% spośród nich nie miała takiej wiedzy przed rozpoczęciem studiów. Zdecydowana większość (ponad 88\%) studentów stwierdziła, że miała taki sam tryb rekrutacji jak inni studenci. Bardzo sporadycznie (2,2\%) pojawiają się informacje o „specjalnym” trybie przyjmowania studenta $\mathrm{z}$ niepełnosprawnością na uczelnię - poza normalną rekrutacją bądź np. poprzez zwolnienie $z$ egzaminu sprawnościowego itp., a w ponad połowie $(56,4 \%)$ przypadków uczelnia nie wymagała składania dokumentów potwierdzających niepełnosprawność przy rekrutacji na studia. W kontekście praktyk niedyskryminacyjnych bardzo niepokoi natomiast taka wypowiedź: $\mathrm{Na}$ (nazwa uczelni) jest limit miejsc dla osób niepetnosprawnych. Uważam to za zbędne $i w$ niektórych przypadkach uwłaczajace. Pomimo wymaganej liczby punktów (drugi najwyższy próg na uczelni, 14 osób na miejsce) $i$ tak przyjęto mnie jako osobe niepełnosprawna "z limitu”. Nikogo o to nie prosiłam, ale samo złożenie orzeczenia sprawiło, że byłam poza rekrutacja. Wyniki były jawne, a przy moim nazwisku widniała gwiazdka i odnośnik w jakim trybie mnie przyjęto. Jestem bardzo mocno przeciwko tego rodzaju „udogodnieniom” (R178).

Wysoko oceniane jest przez studentów przystosowanie ich uczelni do potrzeb osób z różnymi niepełnosprawnościami. Aż 69\% spośród nich ocenia to dostosowanie bardzo dobrze lub dobrze; strukturę odpowiedzi przedstawia wykres 8 . 


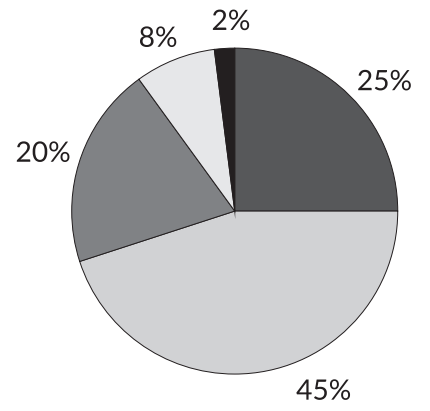

Bardzo dobrze

$\square$ Dobrze

Różnie, to zależy

$\square$ Źle

Bardzo źle

Wykres 8. Ocena dostosowanie uczelni do potrzeb osób z różnymi niepełnosprawnościami

Źródło: opracowanie własne na podstawie badań studentów niepełnosprawnych

Jednocześnie w komentarzach większość badanych skupiała się jednak na dostosowaniu pod kątem barier architektonicznych (choć tylko 3,8\% osób spośród ankietowanych porusza się na wózkach inwalidzkich bądź ma inne problemy z chodzeniem), co świadczyć może o tym, że stereotypowemu postrzeganiu niepełnosprawności ulegają także same osoby niepełnosprawne (por. Ostrowska 2015).

Jakie są specjalne potrzeby niepełnosprawnych studentów związane ze studiowaniem? Wyniki przedstawia wykres 9.

W badanej grupie studentów przeważają osoby potrzebujące przede wszystkim wsparcia finansowego. $\mathrm{Na}$ zwiększone koszty studiowania osób niepełnosprawnych zwracano już uwagę we wcześniejszych badaniach (Sztobryn-Giercuszkiewicz 2011a). Są to m.in. koszty związane z koniecznością dojazdów na uczelnię, wynajmu odpowiedniego mieszkania (jeśli baza domów studenckich nie jest przystosowana do potrzeb osób niepełnosprawnych), koszty dodatkowych leków, np. w przypadku osób po przeszczepach czy o obniżonej odporności, zakupu przystosowanego sprzętu komputerowego itp. Tym samym zasadne wydaje się kontynuowanie wsparcia finansowego studentów nie- 
pełnosprawnych m.in. przez PFRON w postaci Modułu II programu Aktywny Samorząd, dzięki któremu część z tych kosztów można pokryć.

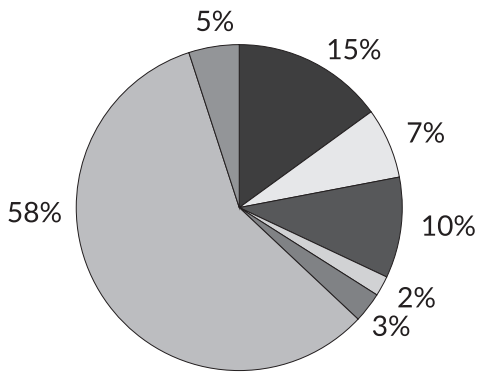

Niczego nie potrzebuję

$\square$ Inne

$\square$ Dostosowanych budynków i sal dydaktycznych

$\square$ Transportu

Pomocy asystenta

$\square$ Stypendium socjalnego

Specjalistycznego sprzętu

Wykres 9. Jakie są specjalne potrzeby niepełnosprawnych studentów związane ze studiowaniem?

Źródło: opracowanie własne na podstawie badań studentów niepełnosprawnych

Prawie połowa $(47,5 \%)$ studentów niepełnosprawnych nie uważa, aby coś stanowiło szczególną przeszkodę $\mathrm{w}$ ich studiowaniu. Ci, którzy takie przeszkody postrzegają (26,6\%), oprócz stanu zdrowia zwracają głównie uwagę na relacje z wykładowcami (brak zrozumienia, niechęć ze strony pracowników uczelni, brak elementarnej wiedzy dotyczącej niepełnosprawności), koszty studiowania, niedostosowanie uczelni oraz ich własne nastawienie wewnętrzne (brak motywacji do studiowania).

Problematyka relacji między studentami niepełnosprawnymi a pracownikami uczelni, zarówno dydaktycznymi, jak i administracyjnymi, była już kilkakrotnie podejmowana w badaniach dotyczących sytuacji studentów niepełnosprawnych na uczelniach (Kulpa 2010, Izdebski 2010). W omawianym badaniu studenci przedstawiają nastawienie wykładowców jako jedną z głównych barier utrudniających im studiowanie. Jednocześnie - większość badanych studentów jest zadowolona z kontaktów z wykładowcami i pracownikami administracji. 


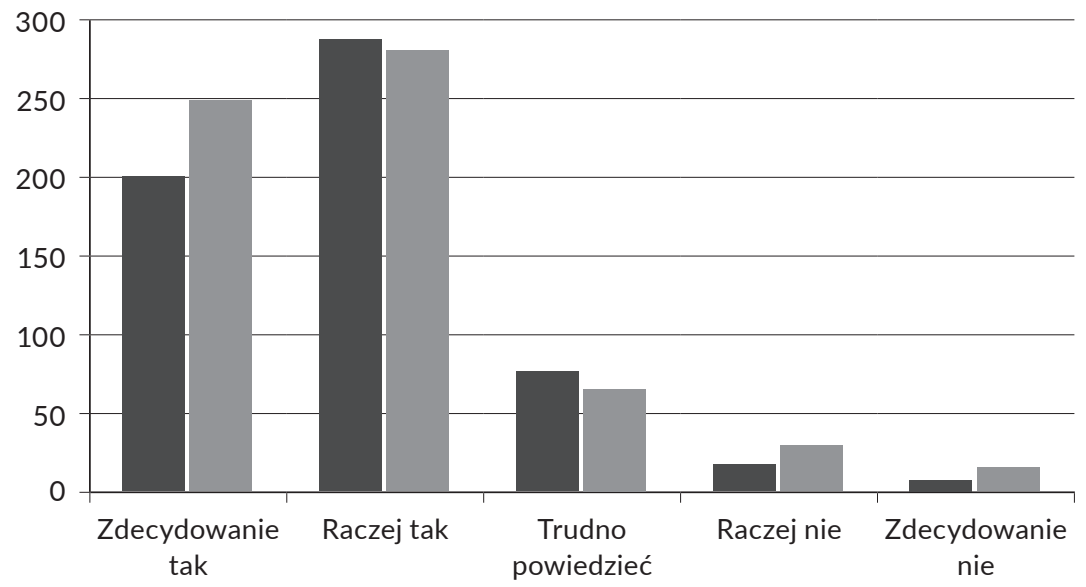

Wykres 10. Rozkład odpowiedzi na pytanie: Czy jesteś zadowolony $\mathrm{z}$ kontaktów z pracownikami uczelni?

Źródło: opracowanie własne na podstawie badań studentów niepełnosprawnych

Badani studenci także w większości (68\%) uważają, że pracownicy uczelni stosują zasadę równości wobec studentów pełno- i niepełnosprawnych. Można to rozumieć w duchu antydyskryminacji, a można i w ten sposób: Dziekanat jest zawsze nieprzyjemnym miejscem [...] ale jest tolerancyjny - Panie z dziekanatu jednakowo źle traktuja i pełno- $i$ niepetnosprawnych (R74). Studenci zwracają również uwagę na niewiedzę pracowników uczelni na temat niepełnosprawności, ich „lękliwe” zachowania w kontakcie z osobą niepełnosprawną: Moim zdaniem [największym problemem jest] podejście wykładowców. Często nie ma $w$ ich świadomości „wypośrodkowanego - normalnego" podejścia do studenta niepelnosprawnego. Czasem przesadzaja $w$ strone litości zamiast zwykłej pomocy, a czasem fakt niepełnosprawności danego studenta puszczaja mimo uszu. Jednakże sq tacy, z którymi bez problemu można się porozumieć (G38). Jeśli 
ankietowani wypowiadają się na temat negatywnych w ich odczuciu reakcji wykładowców w kontakcie ze studentem z niepełnosprawnością, to najczęściej dotyczą one tego typu zachowań:

- uznawanie absencji, indywidualnej organizacji studiów itp. za chęć „migania się”, symulowanie choroby czy wręcz wykorzystywanie swojego stanu zdrowia do wymuszania traktowania ich na innych warunkach niż pozostałych studentów;

- niecierpliwość, niechęć, niezrozumienie problemów studenta;

- okazywanie litości (Coś co mnie bardzo wkurza, to litość. Nie chcemy jej doświadczać, chcemy normalnego traktowania (G44)) (Sztobryn-Giercuszkiewicz 2011b).

Z drugiej strony, nawet studenci, którzy wymieniają jakieś konkretne negatywne sytuacje w kontakcie $\mathrm{z}$ wykładowcą, podkreślają, że są to sytuacje sporadyczne, najczęściej wynikające z nieświadomości i braku wiedzy na temat konkretnego rodzaju niepełnosprawności; badani studenci zwracają również uwagę na fakt, że pośpiech, niecierpliwość i brak chęci wsłuchiwania się w ich problemy ze strony dydaktyków jest konsekwencją egalitarnego modelu kształcenia akademickiego i dotyka na równi wszystkich studentów.

Wypowiedzi studentów dotyczyły także pomysłów na ułatwienie studiowania osobom niepełnosprawnym. Wykres 11 pokazuje rozkład odpowiedzi.

Taki stan rzeczy potwierdza wysuwane wcześniej przez badaczy hipotezy, że:

1. Studenci z niepełnosprawnościami na uczelniach to głównie osoby z mniej widocznymi i lżejszymi schorzeniami, z lekkim lub umiarkowanym stopniem niepełnosprawności (Myśliwiec 2010, Chrzanowska 2013), którzy stosunkowo dobrze i bez specjalnego wspomagania radzą sobie na kolejnych etapach edukacji. Ta grupa różni się od swoich „pełnosprawnych” 


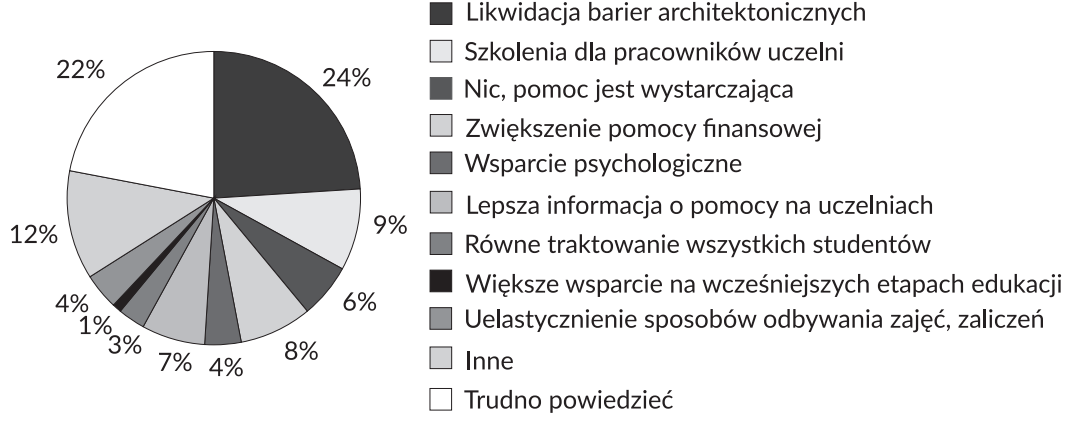

Wykres 11. Rozkład odpowiedzi na pytanie: Co należałoby zrobić w pierwszej kolejności, aby ułatwić studiowanie osobom niepełnosprawnym?

Źródło: opracowanie własne na podstawie badań studentów niepełnosprawnych

kolegów zapewne często tylko faktem posiadania orzeczonej niepełnosprawności;

2. Studenci $\mathrm{z}$ niepełnosprawnościami posiadają małą wiedzę na temat oferty uczelni $\mathrm{w}$ zakresie wsparcia osób niepełnosprawnych, częściowo z powodu braku własnego zainteresowania taką ofertą (ze względu na rodzaj i stopień niepełnosprawności nie mają specjalnych potrzeb), częściowo z powodu niedostatecznego upowszechniania przez uczelnie/BONy takich informacji (Izdebski 2010, Kulpa 2010);

3. Studenci niepełnosprawni raczej nie kierują się przy wyborze uczelni i kierunku studiów (w konsekwencji zawodu) możliwościami i ograniczeniami wynikającymi z ich stanu zdrowia. Tłumaczyć to można znów częściowo faktem doświadczania tylko niewielkich niedogodności z powodu niepełnosprawności i brakiem wpływu tejże na funkcjonowanie w roli studenta i na rynku pracy. Częściowo taki stan rzeczy jest zapewne efektem nieświadomości i braku orientacji 
co do konsekwencji, jakie dane schorzenie może mieć w zakresie możliwości wykonywania pracy zawodowej (por. Giermanowska i in. 2015).

4. Studenci niepełnosprawni generalnie dobrze oceniają przystosowanie swojej uczelni do potrzeb wynikających $\mathrm{z}$ ich niepełnosprawności, również dobrze oceniane są ich relacje $\mathrm{z}$ nauczycielami akademickimi i administracją uczelni. Jeśli zwracają uwagę na jakieś negatywne aspekty tych kontaktów, to ich zdaniem wynikają one: a) z braku odpowiedniego przeszkolenia wykładowców w zakresie różnych rodzajów niepełnosprawności, b) z niezrozumienia faktu, że brak dyskryminacji oznacza równe traktowanie wszystkich, zarówno jeśli chodzi o prawa, jak i wymagania (por. Kulpa 2010).

\section{„INKLUZJA SPOŁECZNA ZACZYNA SIĘ W NASZYCH GŁOWACH" - PERSPEKTYWY I REKOMENDACJE DLA INSTYTUCJI SZKOLNICTWA WYŻSZEGO}

W 2003 r. OECD przeprowadziła w 5 krajach (Kanadzie, Wielkiej Brytanii, Francji, Niemczech i Szwajcarii) badanie, którego celem było zidentyfikowanie czynników utrudniających dostęp do uczelni wyższych i studiowania osobom z niepełnosprawnościami oraz specjalnymi potrzebami edukacyjnymi (SPE). Wyłoniono kilka najważniejszych barier, spowalniających proces inkluzji w edukacji na poziomie wyższym:

- finansowanie, w szczególności zaś brak spójnego modelu finansowania i jego źródeł;

- stosunek do specjalnych potrzeb edukacyjnych na poziomie ośrodków decyzyjnych, ale także wśród pracowników uczelni; 
- brak porozumienia i współpracy pomiędzy uczelniami a pozostałymi sektorami edukacyjnymi, w szczególności szkolnictwem ponadpodstawowym;

- brak elastyczności w oferowaniu alternatywnych, zróżnicowanych form kształcenia dla wielu studentów;

- fizyczna dostępność obiektów uczelni;

- rozbieżność pomiędzy celami programu, jego zawartością a indywidualnymi potrzebami;

- brak zrozumienia faktu, że SPE to wynik wzajemnego oddziaływania trudności studenta ze środowiskiem, w jakim się znajduje;

- brak wiarygodnych informacji, na których można oprzeć badania, a następnie rekomendacje ${ }^{36}$.

Należy stwierdzić, że wyniki badań przeprowadzonych ponad 10 lat później w polskich uczelniach potwierdzają istnienie każdego $\mathrm{z}$ tych problemów $\mathrm{w}$ systemie polskiego szkolnictwa wyższego. Mimo wielu zmian, niewątpliwie na lepsze, nadal istnieją liczne bariery utrudniające czy wręcz uniemożliwiające pełne uczestnictwo osób niepełnosprawnych w różnych aspektach życia społecznego, w tym edukacji akademickiej. Często są to bariery architektoniczne lub finansowe - pewna grupa niepełnosprawnej młodzieży nie rekrutuje się w ogóle na uczelnie, a o skali tego zjawiska badacze niewiele mogą powiedzieć. Bardzo przeszkadza źle sformułowane prawo, brak przejrzystych przepisów co do sposobu wykorzystania dotacji ministerialnej, wykluczenie z systemu osób nieposiadających orzeczonej niepełnosprawności. Najtrudniejsze są jednak zmiany mentalne i dotyczy to nastawienia zarówno ludzi "pełnosprawnych” - pracowników uczelni, wykładowców i grup studenckich, jak i samych osób z niepełnosprawnością, które poprzez różne strategie „zarządzania stygmatem” (Goffman 2007;

36 Organisation for Economic Cooperation and Development, Disability in Higher Education, Paris 2003. 
Leszczyńska 2010) utrudniają proces „wtopienia się” osób niepełnosprawnych w środowisko uczelniane.

Polskie szkolnictwo wyższe jest $\mathrm{z}$ całą pewnością na dobrej drodze ku inkluzji osób niepełnosprawnych, będąc ze swej natury „włączające”37, choć droga ta na pewno będzie jeszcze długa i wyboista. Cytując ponownie B. Gąciarz (Pełnomocnik Rektora ds. Osób Niepełnosprawnych w Akademii Górniczo-Hutniczej w Krakowie): „Uczelnie wyższe nie są wolne od tych wszystkich negatywnych obciążeń w polityce wobec osób niepełnosprawnych, które są charakterystyczne dla całego społeczeństwa, ale też ze względu na swój szczególny status instytucji, które mają powinność realizowania najwyższych cywilizacyjnych standardów postępowania wobec każdego, kto wyraża wolę i gotowość zdobywania wykształcenia, wprowadzają w życie specjalne rozwiązania organizacyjne i programy społeczne, których celem jest umożliwienie osobom niepełnosprawnym adaptacji do świata akademickiego i korzystanie z szans, który on oferuje" (Gąciarz 2010: 26).

Jakie zatem kroki powinny podjąć polskie instytucje szkolnictwa wyższego, by realizować prawo równego dostępu osób niepełnosprawnych do kształcenia i przeciwdziałać wykluczeniu tej grupy, jednocześnie stwarzając szanse na „normalne" funkcjonowanie edukacyjne, społeczne i zawodowe tych osób? Wnioski wyciągnięte ze zrealizowanych badań pozwalają na stworzenie zbioru poniższych rekomendacji, nie jest on jednak ani wyczerpujący, ani zamknięty. Proces, w którym obecność studenta z niepełnosprawnością na polskiej uczelni jest codziennością i standardem, a nie wyjątkiem i czymś „poza normą”, dopiero się rozpoczął. Z pewnością czas przyniesie zmiany, które pozwolą na dopi-

$37 \mathrm{Na}$ świecie istnieją różne modele kształcenia akademickiego osób niepełnosprawnych, wśród których zdecydowanie przeważa model ,integracyjny”. Bywają jednakże uczelnie „specjalne”, jak np. Uniwersytet Gallaudeta w Waszyngtonie dla osób głuchych. Językiem wykładowym jest tam Amerykański Język Migowy. 
sanie kolejnych punktów do poniższych zaleceń. A może czego sobie wszyscy życzymy - niektóre z nich będzie można już usunąć, bo bariery te będą dawno pokonane?

Rekomendacje dla systemu szkolnictwa wyższego i instytucji otoczenia w obszarze kształcenia osób z niepełnosprawnościami:

- informowanie uczelni, jakie rozwiązania funkcjonują jako „dobre praktyki” i w jaki sposób możliwe jest ich sfinansowanie - dotyczy to przede wszystkim możliwości wykorzystania dotacji ministerialnej, co do której narosło wiele wątpliwości w środowisku uczelnianym;

- zwiększanie świadomości niepełnosprawności wśród pracowników uczelni, szkolenie w zakresie specjalnych potrzeb edukacyjnych i dydaktyki osób dorosłych z niepełnosprawnościami;

- stopniowe niwelowanie barier architektonicznych, infrastrukturalnych, cyfrowych, doposażenie uczelni w specjalistyczne sprzęty wspomagające kształcenie osób z niepełnosprawnościami;

- zatrudnianie specjalistów, w szczególności osób zajmujących wspieraniem kształcenia studentów niepełnosprawnych, asystentów osób niepełnosprawnych, psychologów, coachów, doradców zawodowych, tyfloi surdopedagogów, tłumaczy języka migowego, konsultantów edukacyjnych;

- informowanie niepełnosprawnej młodzieży kończącej szkoły średnie o możliwościach kształcenia na uczelniach w Polsce i za granicą;

- systemowa, zintegrowana współpraca międzyuczelniana na poziomie instytucji rządowych i samorządowych (uczelnie i MNiSW, PFRON) ze szkolnictwem ponadpodstawowym, organizacjami pozarządowym i zrzeszającymi studentów z niepełnosprawnością oraz pracodawcami z otwartego rynku pracy;

- aktywizacja środowiska studentów niepełnosprawnych, poprzez włączanie tej grupy w działania na rzecz osób 
niepełnosprawnych na uczelni, tworzenie lub włączanie ich do organizacji studenckich, reprezentacja w Samorządach Studenckich itp.;

- zwiększenie efektywności działalności uczelnianych Biur ds. Osób Niepełnosprawnych poprzez upowszechnianie informacji o udzielanym wsparciu, współpracę ze studentami niepełnosprawnymi przy wypracowywaniu najlepszych rozwiązań, przeprowadzanie diagnozy rzeczywistych potrzeb studentów, monitorowanie efektów tych działań.

Warty podkreślenia wydaje się fakt, że wraz z postępującym procesem dostosowania polskich uczelni i wzrastającą dostępnością dla osób niepełnosprawnych, nie tylko dba się o realizację fundamentalnych wartości i praw, ale także polepsza się w uczelniach jakość zarządzania i kształcenia, bezpieczeństwo i infrastruktura dydaktyczna. Bowiem, przytaczając słowa Bengta Lindqvista, Specjalnego Sprawozdawcy Narodów Zjednoczonych ds. Standardowych Zasad Wyrównywania Szans Osób Niepełnosprawnych, „szkoła lepsza dla osób z niepełnosprawnościami jest szkołą lepszą dla wszystkich".

\section{BIBLIOGRAFIA}

Barnes Colin, Mercer Geof (2004), Disability, Polity Press, Cambridge.

Berger Peter Lee, Luckmann Thomas (1983), Społeczne tworzenie rzeczywistości, PIW, Warszawa.

Byra Stanisława (2010), Mechanizmy kształtowania się stereotypów dotyczacych osób z niepetnosprawnością, [w:] Maria Chodkowska, Stanisława Byra, Zdzisław Kazanowski (red.), Stereotypy niepełnosprawności. Między wykluczeniem a integracją, Wydawnictwo KUL, Lublin, s. 33-48.

Chodkowska Maria (2010), Źródła stereotypów niepetnosprawności i osób niq obciążonych w kręgu kultury europejskiej, [w:] Maria Chodkowska, Stanisława Byra, Zdzisław Kazanowski 
(red.), Stereotypy niepełnosprawności. Między wykluczeniem a integracja, Wydawnictwo KUL, Lublin, s. 13-31.

Dostępność edukacji akademickiej dla osób z niepełnosprawnościami. Analiza i zalecenia, Biuletyn Rzecznika Praw Obywatelskich 2015, nr 5, Zasada równego traktowania. Prawo i praktyka, nr 16, Warszawa, ss. 62.

Ferenz Krystyna (2008), Źródła kształtowania się postaw wobec osób niepetnosprawnych, [w:] Grażyna Miłkowska, Bożena Olszak-Krzyżanowska (red.), Teraźniejszość i przyszłość osób niepełnosprawnych $w$ kontekście społecznych zmian, Oficyna Wydawnicza „Impuls”, Kraków, s. 97-104.

Gąciarz Barbara (2002), Warunki życia i aktywność społeczna niepełnosprawnych studentów AGH. Postawy pracowników i studentów AGH wobec osób niepelnosprawnych. Raport z badań, Wydział Nauk Społecznych Stosowanych (maszynopis), Kraków.

Gąciarz Barbara (2010), Niepetnosprawni studenci w społeczności akademickiej. Źródła sukcesów i porażek w integracji społecznej i aktywności zawodowej, Wydawnictwo IFIS PAN, Warszawa.

Gąciarz Barbara, Rudnicki Seweryn (2014), Polscy niepetnosprawni. Od kompleksowej diagnozy do nowego modelu polityki społecznej, Wydawnictwo AGH, Kraków.

Giermanowska Ewa, Kumaniecka-Wiśniewska Agnieszka, Racław Mariola, Zakrzewska-Manterys Elżbieta (2015), Niedokończona emancypacja. Wejście niepetnosprawnych absolwentów szkół wyższych na rynek pracy, Wydawnictwo Uniwersytetu Warszawskiego, Warszawa.

Goffman Erving (2007), Piętno. Rozważania o zranionej tożsamości, GWP, Gdańsk.

Gustavsson Anders, Zakrzewska-Manterys Elżbieta (1997), Upośledzenie w społecznym zwierciadle, Wydawnictwo Akademickie „Żak”, Warszawa.

Inglot-Brzęk Elżbieta (2012), Przemiany demograficzne a rozwój szkolnictwa wyższego w Polsce, „Nierówności Społeczne a Wzrost Gospodarczy”, z. 26, Modernizacja dla spójności społeczno-ekonomicznej w czasach kryzysu, Rzeszów, s. 216-229. Izdebski Albert (2010), Niepełnosprawni studenci na Uniwersytecie Warszawskim, [w:] Barbara Gąciarz (red.), Niepetnosprawni 
studenci w społeczności akademickiej, Wydawnictwo IFIS PAN, Warszawa, s. 164-180.

Kulpa Anna (2010), Funkcjonowanie osób niepełnosprawnych w roli studenta, [w:] Barbara Gąciarz (red.), Niepetnosprawni studenci w społeczności akademickiej, Wydawnictwo IFIS PAN, Warszawa, s. 118-146.

Leszczyńska Katarzyna (2010), Tożsamość i stygmatyzacja $w$ narracjach niepetnosprawnych studentów, [w:] Barbara Gąciarz (red.), Niepełnosprawni studenci w społeczności akademickiej, Wydawnictwo IFIS PAN, Warszawa, s. 35-55.

Myśliwiec Maciej (2010), Profil społeczno-demograficzny, poziom zadowolenia $z$ życia i obawy niepełnosprawnych studentów, [w:] Barbara Gąciarz (red.), Niepetnosprawni studenci w społeczności akademickiej, Wydawnictwo IFIS PAN, Warszawa, s. $56-70$.

Ostrowska Antonina (2015), Niepełnosprawni w społeczeństwie 1993-2013, Wydawnictwo IFIS PAN, Warszawa.

Ośrodek Rozwoju Edukacji (2015), Dziecko z niepełnosprawnościa w przedszkolu i szkole ogólnodostępnej - wyzwania dla JST, Warszawa.

Połtyn-Zaradna Katarzyna, Waszkiewicz Ludmiła, Zatońska Katarzyna (2009), Dlaczego niepetnosprawny student jest „niewidoczny”?, „Problemy Higieny i Epidemiologii”, t. 90 nr 3, s. 374-377.

Równe szanse $w$ dostępie do edukacji osób $z$ niepetnosprawnościami. Analiza i zalecenia, Biuletyn Rzecznika Praw Obywatelskich 2012, nr 7, Zasada równego traktowania. Prawo i praktyka, nr 3, Warszawa.

Struck-Peregończyk Monika (2013), Wizerunek osób niepetnosprawnych w środkach masowego przekazu - zarys zjawiska, Kwartalnik Internetowy „Komunikacja Społeczna”, nr 4 (8), s. $22-31$.

Sztobryn-Giercuszkiewicz Joanna (2011a), Formy wsparcia osób niepetnosprawnych studiujacych $w$ łódzkich uczelniach wyższych, [w:] Wielisława Warzywoda-Kruszyńska, Grażyna Mikołajczyk-Lerman (red.), Uczeń i student niepełnosprawny - warunki życia i nauki, Wydawnictwo UŁ, Łódź, s. 99-114.

Sztobryn-Giercuszkiewicz Joanna (2011b), Barriers in academic learning of persons with disabilities in Lodz higher education institutions - research report, [w:] Aleksandra Polak-Sopiń- 
ska, Joanna Lacewicz-Bartoszewska (red.), Ergonomics for the Disabled. Education as the Basis of Quality of Life for People with Disabilities, Wydawnictwo Politechniki Łódzkiej, Łódź, s. 9-29.

Śleboda Renata (2012), Kierunek i poziom wykształcenia oraz aktywność zawodowa osób z niepełnosprawnością, „Niepełnosprawność - zagadnienia, problemy, rozwiązania”, nr II/2012(3), s. $107-130$.

Tylewska-Nowak Beata, Dykcik Władysław (2013), Student z niepetnosprawnościa w szkole wyższej, Wydawnictwo UAM, Poznań.

Znaniecki Florian (1997), Społeczna rola studenta uniwersytetu, Wydawnictwo Nakom, Poznań.

\section{ALTER IDEM PRINCIPLE - A STUDENT WITH A DISABILITY IN THE HIGHER EDUCATION SYSTEM}

\section{(Summary)}

The author presents the situation of students with disabilities in the Polish system of higher education. This paper discusses for the first time the history of educational support systems development for students with disabilities at Polish universities. Two research approaches were presented: the higher educational institutions' perspective and the students' with disabilities perspective. The author presents latest research findings, the best practices and the recommendations to the higher education system for increased inclusion of persons with disabilities in higher education.

Keywords: disability, student, HE institutions, inclusive education, social inclusion. 